\title{
Synthesis of Polycycles by Single or Double Domino Nucleophilic Substitution/Diels-Alder Reaction
}

(1)

(1)

(1)

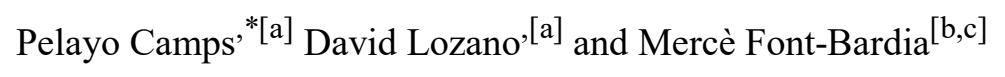

Keywords: Synthetic methods / Domino reactions / Nucleophilic substitution / Cycloaddition / Cyclization / Polycycles

[a] Laboratori de Química Farmacèutica (Unitat Associada al CSIC), Facultat de Farmàcia, Universitat de Barcelona, and Institut de Biomedicina (IBUB), Universitat de Barcelona, Av. Joan XXIII 27-31, 08028 Barcelona, Spain

E-mail: camps@ub.edu

http://www.ub.edu/farmaco/

[b] Departament de Cristal·lografia, Mineralogia i Dipòsits Minerals, Universitat de Barcelona, Martí Franquès s/n, 08028 Barcelona, Spain

[c] Unitat de Difracció de RX, Centres Científics i Tecnològics de la Universitat de Barcelona (CCiTUB), Universitat de Barcelona, Solé i Sabarís 1-3, 08028 Barcelona, Spain (Spain) 
34 ABSTRACT:

35

36 New hexacyclo and octacyclo compounds have been synthesized by a short route whose key step

37 consists of a single or double domino nucleophilic substitution of neopentyl-type iodides with potassium

38 cyclopentadienide, followed by intramolecular Diels-Alder cycloaddition. 
42 Polycyclic and cage compounds are of current interest in medicinal chemistry.[1-4] In connection with

43 this potential application, we recently described the synthesis of a 2,8-ethanonoradamantane

44 derivative.[5] Diamondoid derivatives[6] are of interest in connection with host-guest molecular

45 recognition, materials chemistry, molecular machines and rotors, etc. Polytwistanes[7,8] are being

46 studied as chiral hydrocarbon nanotubes, and polynorbornane derivatives[9] have been used to prepare

47 coordination cages (Figure 1). In this paper, a short route to functionalized bridged di- and tri-

48 norbornane derivatives is described. These compounds might be used, among other applications, as new

49 scaffolds for the preparation of biologically active compounds, or as building blocks for the synthesis of

50 new polynorbornanebased ligands. 
An important feature of these syntheses was the preparation of cyclopenta-2,4-diene-1,1diylbis(methylene) diacetate (6) according to Scheme 1. Dimethyl bisallylmalonate (1) $[10,11]$ was transformed into dimethyl cyclopent-3-ene-1,1-dicarboxylate (2) by reaction with Grubbs first generation catalyst. Compound 2 was alternatively prepared by reaction of dimethyl malonate with cis1,4-dichloro-2-butene.[12] Reduction of diester 2 followed by acetylation gave known diacetate 4 . Reaction of 4 with N-bromosuccinimide (NBS) in the presence of 2,2 -azo-bis(isobutyronitrile) (AIBN) as described in a related case,[13] gave allylic bromide 5, which, on reaction with quinoline at high temperature,[14] gave the desired diacetate (i.e., 6).

Reaction of cyclopentadiene 6 with dimethyl acetylenedicarboxylate (1.5 equiv.) gave the corresponding Diels-Alder adduct 7 in good yield (Scheme 2). Methanolysis of the acetate groups of this compound with $\mathrm{K} 2 \mathrm{CO} 3$ in $\mathrm{MeOH}$ gave a stereoisomeric mixture of alcohols 8 and 9 in a ratio 8/9 of about 9:1 [on the basis of integration of the singlet signals of one of the COOMe groups of $8(\delta=3.70 \mathrm{ppm})$ and $9(\delta$ $=3.57 \mathrm{ppm}$ ) in the $1 \mathrm{H}$ NMR spectrum of the mixture]. These compounds are reasonably formed by Michael addition of the syn alcohol functionality of the intermediate diol onto the butenedioate substructure. Compound 8 was isolated as a racemate from its mixture with 9 by crystallization from EtOAc, and was fully characterized spectroscopically. The exo stereochemistry of the ester functionality at C-7 was clearly assigned on the basis of its $1 \mathrm{H}$ NMR spectrum, in which the 7-H proton appears as a singlet as the value of its coupling constant with 4-H is close to zero (dihedral angle $\mathrm{H}-\mathrm{C}-7-\mathrm{C}-4-\mathrm{H}$ close to $90^{\circ}$ ). The stereochemistry of 8 was also secured by X-ray diffraction analysis. Figure 2 shows the ORTEP representation of one of the enantiomers. The synthetic sequence was continued with racemic alcohol 8. Mesylation of 8 by a standard procedure gave mesylate 10, which was transformed into iodide 11 by reaction with $\mathrm{NaI}$ in acetone. Both transformations took place in good yield.

Treatment of this iodide with potassium cyclopentadienide in DMF in the presence of 18-crown-6 (5 mol-\%)[15,16] gave polycycle 12 , as a result of nucleophilic substitution of the neopentyl-type iodide by the cyclopentadienide anion, followed by intramolecular Diels-Alder reaction, in good yield. Although polycycle 12 was fully characterized spectroscopically, and by elemental analysis and accurate mass measurement, its structure was secured by X-ray diffraction analysis. Figure 3 shows the ORTEP representation of one of the enantiomers of 12 .

Acid-catalyzed methanolysis of diacetate 7 gave a mixture of diol 13 plus alcohols 8 and 9 in a ratio about 20:12:5 (by 1H NMR spectroscopy; Scheme 3). From this mixture, diol 13 could not be isolated in pure form since partial conversion into alcohols 8 and 9 took place during attempted purification by silica gel column chromatography. Consequently, the above mixture was transformed into a mixture of dimesylate 14 and monomesylate 10 and its $\mathrm{C}-7$ epimer. Upon treatment with $\mathrm{NaI}$ in acetone, this mixture gave a mixture of diiodide 15 and monoiodide 11 and its C-7 epimer. This mixture was separated by silica gel column chromatography into two fractions: diiodide 15 (31\% overall yield from diacetate 7), and a mixture of monoiodide 11 and its C-7 epimer (28\% overall yield from 7 ).

Reaction of diiodide 15 with potassium cyclopentadienide as before gave polycycle 26 in $49 \%$ yield. The formation of this compound implies a double nucleophilic substitution of the neopentyl-type iodides by the cyclopentadienide anion, followed by a double intramolecular Diels-Alder reaction. Compound 16 was fully characterized analytically and spectroscopically, including X-ray diffraction analysis. Figure 4 shows the ORTEP representation of polycycle 16.

To the best of our knowledge, although these domino processes appear conventional, the only related transformation described to date[17] is the reaction of a stereoisomeric mixture of dimethyl 7(dimethoxymethyl)norborna-2,5-diene-2,3-dicarboxylate with trimethylsilylcyclopentadiene catalyzed 
99 by TiCl4. This gave a mixture, which was not separated, of products of condensation and Diels-Alder 100 addition.

101 
103

104 In conclusion, a short route to complex functionalized polycycles that could be of interest as new

105 scaffolds for the preparation of biologically active compounds and coordination cages has been

106 developed. The key points of the synthesis are: (i) a convenient preparation of 1,1-disubstituted

107 cyclopentadiene 6, and (ii) a single or double domino nucleophilic substitution of neopentyl-type iodides

108 by cyclopentadienide anion/Diels-Alder reaction that introduces three or six new rings into the

109 corresponding products, i.e., 11 or 15 respectively, in a one-pot transformation. 
General Methods: Melting points were determined in open capillary tubes with an MFB 595010M Gallenkamp melting-point apparatus. 1H and 13C NMR spectra were recorded with a Varian Mercury 400 (400 MHz for $1 \mathrm{H} ; 100.6 \mathrm{MHz}$ for 13C) spectrometer in CDCl3. Chemical shifts $(\delta)$ are reported in parts per million relative to tetramethylsilane, and spectra were calibrated using internal tetramethylsilane or residual $\mathrm{CHCl} 3 / \mathrm{CDCl} 3$. Multiplicities are reported using the following abbreviations: s, singlet; $d$, doublet; $t$, triplet; $m$, multiplet; br, broad, or their combinations. Assignments given for the NMR spectra are based on DEPT, COSY, NOESY, 1H/13C single quantum correlation (gHSQC sequence), and 1H/13C multiple bond correlation (gHMBC sequence) spectra. IR spectra were recorded with an FTIR Perkin-Elmer Spectrum RX1 spectrometer using the attenuated total reflectance (ATR) technique. Absorption values are given as wavenumbers $(\mathrm{cm}-1)$, and the intensity of the absorptions are given as strong (s), medium (m), or weak (w). High-resolution mass spectra (HRMS) were carried out at the mass spectrometry unit of the Centres Científics i Tecnològics de la Universitat de Barcelona (CCiTUB) with an LC/MSD-TOF spectrometer with electrospray ionization (ESI-TOFMS) from Agilent Technologies. Elemental analyses were carried out at the IIQAB (CSIC) of Barcelona, Spain, with elemental microanalyzers (A5) model Flash 1112 series and (A7) model Flash 2000 series from Thermofinnigan for $(\mathrm{C}, \mathrm{H}, \mathrm{N})$ and $(\mathrm{C}, \mathrm{H}, \mathrm{N}, \mathrm{S})$ determinations, respectively. Silica gel 60 AC (35-70 mm, SDS, ref. 2000027) was used for flash column chromatography. The eluents used are reported as volume/volume percentages. Thin-layer chromatography (TLC) was carried out on aluminum-backed sheets with silica gel 60,254 nm indicator (Fluka-Sigma-Aldrich), and spots were visualized with UV light or a solution of $\mathrm{KMnO} 4$ (1\% aq.). X-ray diffraction analysis was carried out with a D8 Venture diffractometer at the CCiTUB of the University of Barcelona. Allyl bromide, NBS, 18-crown-6, 4-(dimethylamino)pyridine, dimethyl acetylenedicarboxylate, dimethyl malonate, Grubbs first generation catalyst, $\mathrm{KH}$ (30 \%), LiAlH4, and p-toluenesulfonic acid were obtained from SigmaAldrich; AIBN, dicyclopentadiene, and quinoline were obtained from Fluka; all of these reagents were used without further purification.

(4-Bromocyclopent-2-ene-1,1-diyl)bis(methylene) Diacetate (5): NBS (856 mg, $4.81 \mathrm{mmol}$ ) and AIBN (79 mg, $0.48 \mathrm{mmol}, 10 \mathrm{~mol}-\%$ ) were added to a magnetically stirred solution of diacetate 4 (1.02 $\mathrm{g}, 4.81 \mathrm{mmol})$ in $\mathrm{CCl} 4(14.6 \mathrm{~mL})$ under an Ar atmosphere. The resulting orange-colored stirred suspension was heated at $65^{\circ} \mathrm{C}$ for $15 \mathrm{~min}$, and then at $90{ }^{\circ} \mathrm{C}$ for $1 \mathrm{~h}$. The grey suspension was then cooled with an ice/water bath; the solid precipitate was removed by filtration, and washed with cold $\mathrm{CH} 2 \mathrm{Cl} 2(3 \square 5 \mathrm{~mL})$. The combined filtrate and washings were washed with saturated aqueous $\mathrm{NaHCO} 3$ (3ם $10 \mathrm{~mL}$ ) and brine $(10 \mathrm{~mL}$ ), dried (anhydrous Na2SO4), and concentrated in vacuo to give crude bromide $5(1.31 \mathrm{~g}, 94 \%)$ as a yellow oil, which was used as such in the next step. Rf (hexane/EtOAc, 1:1): 0.42. IR (ATR): $v^{\sim}=3067(\mathrm{w}), 2952(\mathrm{~m}), 2893(\mathrm{w}), 1736(\mathrm{~s}), 1466(\mathrm{~m}), 1437$ (m), 1379 (s), 1364 (s), $1232(\mathrm{~s}), 1183(\mathrm{~m}), 1043(\mathrm{~s}), 981(\mathrm{~m}), 906(\mathrm{~m}), 809(\mathrm{~m}), 786(\mathrm{~m}), 765(\mathrm{~m}) \mathrm{cm}-1$. HRMS: calcd. for [C11H15 79BrO4 + H] 291.0226; found 292.0219. 1H NMR: $\delta=2.05(\mathrm{~s}, 3 \mathrm{H})$ and $2.09(\mathrm{~s}, 3 \mathrm{H})(2$ CH3COO), 2.35 (dd, J = 15.6, $\mathrm{J}=2.4 \mathrm{~Hz}, 1 \mathrm{H}, 5-\mathrm{Ha}), 2.47(\mathrm{dd}, \mathrm{J}=15.6, \mathrm{~J}=7.6 \mathrm{~Hz}, 1 \mathrm{H}, 5-\mathrm{Hb})$, $3.95(\mathrm{~d}, \mathrm{~J}=11.0 \mathrm{~Hz}, 1 \mathrm{H})$ and $4.10(\mathrm{~d}, \mathrm{~J}=11.0 \mathrm{~Hz}, 1 \mathrm{H})(\mathrm{CH} 2 \mathrm{OAc}), 4.20(\mathrm{~s}, 2 \mathrm{H}, \mathrm{CH} 2 \mathrm{OAc}), 5.05-5.08$ $(\mathrm{ddt}, \mathrm{J}=7.6, \mathrm{~J}=2.4, \mathrm{~J}=0.8 \mathrm{~Hz}, 1 \mathrm{H}, 4-\mathrm{H}), 5.80(\mathrm{~d}, \mathrm{~J}=5.6 \mathrm{~Hz}, 1 \mathrm{H}, 2-\mathrm{H}), 6.08(\mathrm{dd}, \mathrm{J}=5.4, \mathrm{~J}=$ $2.2 \mathrm{~Hz}, 1 \mathrm{H}, 3-\mathrm{H}) \mathrm{ppm} .13 \mathrm{C}$ NMR: $\delta=20.75(\mathrm{CH} 3)$ and $20.85(\mathrm{CH} 3)(2 \mathrm{OCOCH} 3), 41.0(\mathrm{CH} 2, \mathrm{C}-5)$, $52.7(\mathrm{CH}, \mathrm{C}-4), 53.5(\mathrm{C}, \mathrm{C}-1), 65.6(\mathrm{CH} 2)$ and $66.7(\mathrm{CH} 2,2 \mathrm{CH} 2 \mathrm{OAc}), 135.7(\mathrm{CH})$ and $136.0(\mathrm{CH}, \mathrm{C}-2$ and $\mathrm{C}-3), 170.7(\mathrm{C})$ and 170.8 (C, $2 \mathrm{CH} 3 \mathrm{COO}) \mathrm{ppm}$. 
Cyclopenta-2,4-diene-1,1-diylbis(methylene) Diacetate (6): A magnetically stirred solution of bromo diacetate $5(3.79 \mathrm{~g}, 13.0 \mathrm{mmol})$ in anhydrous quinoline $(6.9 \mathrm{~mL}, 58.6 \mathrm{mmol})$ under an Ar atmosphere was heated at $180^{\circ} \mathrm{C}$ for $1 \mathrm{~h}$. The dark mixture was cooled with an ice/water bath, then Et2O $(15 \mathrm{~mL})$ was added. The mixture was stirred for $5 \mathrm{~min}$, and then it was washed with $\mathrm{HCl}(2 \mathrm{n}$ aq.; $4 \square 10 \mathrm{~mL})$ and water $(20 \mathrm{~mL})$. The brown organic phase was dried (anhydrous Na2SO4), and concentrated in vacuo to give diene $6(2.38 \mathrm{~g}, 88 \%)$ as a brown oil, which was used as such in the next step. An analytical sample of 6 was obtained by column chromatography of a sample of the above product (205 mg) [35-70 $\mu \mathrm{m}$ silica gel $(6.1 \mathrm{~g})$, pentane/EtOAc mixtures]. On elution with pentane/EtOAc, 96:4, diene $6(165 \mathrm{mg})$ was isolated as a pale yellow oil that solidified on standing. m.p. $42-43{ }^{\circ} \mathrm{C}$. $\mathrm{Rf}$ (silica gel, $10 \mathrm{~cm}$, hexane/EtOAc, 1:1): 0.56. IR (ATR): $v^{\sim}=3076(\mathrm{w}), 2978(\mathrm{~m}), 2959(\mathrm{~m}), 2897(\mathrm{~m}), 2850(\mathrm{w}), 1736(\mathrm{~s})$, $1466(\mathrm{~m}), 1430(\mathrm{~m}), 1376$ (s), 1227 (s), $1078(\mathrm{~m}), 1032$ (s), 978 (s), $922(\mathrm{~m}), 896(\mathrm{~m}), 753$ (s) cm-1. C11H14O4 (210.23): calcd. C 62.85, H 6.71; found C 62.97, H 6.90. HRMS: calcd. for [C11H14O4 + $\mathrm{NH} 4]+228.1230$; found 228.1233; calcd. for [C11H14O4 + H]+211.0965; found 211.0965. 1H NMR: $\delta=2.08$ (s, 6 H, 2 CH3COO), 4.07 (s, 4 H, 2 CH2OAc), 6.33-6.35 [m, 2 H, 2(5)-H], 6.47-6.48 [m, 2 H, 3(4)-H] ppm. 13C NMR: $\delta=20.9(\mathrm{CH} 3,2 \mathrm{OCOCH} 3), 59.5$ (C, C-1), 63.6 (CH2, 2 CH2OAc), 133.6 [CH, C-2(5)], 137.4 [CH, C-3(4)], 170.7 (C, 2 CH3COO) ppm.

Dimethyl 7,7-Bis(acetoxymethyl)bicyclo[2.2.1]hepta-2,5-diene-2,3-dicarboxylate (7): A solution of crude diene $6(624 \mathrm{mg}, 2.97 \mathrm{mmol})$ and dimethyl acetylenedicarboxylate $(0.55 \mathrm{~mL}, 633 \mathrm{mg}, 4.45 \mathrm{mmol})$ in toluene $(5 \mathrm{~mL})$ was heated at $80^{\circ} \mathrm{C}$ for $72 \mathrm{~h}$. The solution was then cooled to room temperature, and the solvent was removed in vacuo. The brown oily residue was subjected to column chromatography [35-70 $\mu \mathrm{m}$ silica gel (25 g), hexane/EtOAc mixtures]. On elution with hexane/EtOAc, 3:1, adduct 7 (820 mg, 78\%) was isolated as a pale yellow oil. Rf (silica gel, $10 \mathrm{~cm}$, hexane/EtOAc, 3:7): 0.47. IR (ATR): $v^{\sim}=3000(\mathrm{w}), 2955(\mathrm{w}), 1731(\mathrm{~s}), 1713(\mathrm{~s}), 1630(\mathrm{~m}), 1435(\mathrm{~m}), 1376(\mathrm{~m}), 1366(\mathrm{~m}), 1317(\mathrm{~m})$, 1218 (s), 1099 (m), 1031 (s), 734 (m) cm-1. C17H20O8 (352.34): C 57.95, H 5.72\%; found C 57.98, H 5.89\%. HRMS: calcd. for [C17H20O8 $+\mathrm{H}]+353.1231$; found 353.1239. $1 \mathrm{H}$ NMR: $\delta=2.028(\mathrm{~s}, 3 \mathrm{H})$ and 2.031 (s, $3 \mathrm{H}, 2 \mathrm{CH} 3 \mathrm{COO}), 3.74$ [pseudo t, J = 2.0 Hz, $2 \mathrm{H}, 1(4)-\mathrm{H}$ ], 3.79 [s, $6 \mathrm{H}, \mathrm{C}-2(3)-\mathrm{COOMe}$ ], 4.25 (s, 2 H, syn-CH2OAc) and 4.29 (s, 2 H, anti CH2OAc), 6.87 [pseudo t, J = 2.2 Hz, 2 H, 5(6)-H] ppm. NOESY: irradiation at $\delta=6.87 \mathrm{ppm}$ shows an NOE with the protons appearing at $\delta=3.74$ [1(4)$\mathrm{H}]$ and 4.25 (syn-CH2OAc) ppm. 13C NMR: $\delta=20.7$ (CH3, CH3COO), 20.8 (CH3, CH3COO), 52.2 (CH3, 2 COOCH3), 56.7 [CH, C-1(4)], 63.7 (CH2, CH2OAc), 63.8 (CH2, CH2OAc), 85.7 (C, C-7), 140.9 [CH, C-5(6)], 150.2 [C, C-2(3)], 164.7 [C, C-2(3)-COOMe], 170.50 (C, anti-CH3COO), 170.54 (C, syn-CH3COO) ppm. Dimethyl (1RS,3aRS,4SR,6aSR,7SR)-3a-(Hydroxymethyl)-3,3a,4,6atetrahydro-1H-1,4-methanocyclopenta[c]furan-1,7-dicarboxylate (8): Anhydrous K2CO3 (40 mg, 0.29 $\mathrm{mmol}$ ) was added to a solution of diacetate $7(413 \mathrm{mg}, 1.17 \mathrm{mmol})$ in anhydrous $\mathrm{MeOH}(2.5 \mathrm{~mL})$, and the mixture was stirred at $30{ }^{\circ} \mathrm{C}$ for $2 \mathrm{~h}$. The mixture was cooled to $0{ }^{\circ} \mathrm{C}$ (ice/water bath), and filtered. The solid was washed with $\mathrm{MeOH}(4 \square 5 \mathrm{~mL}$ ). The combined filtrate and washings were concentrated in vacuo to give a brown solid (369 mg), containing a stereoisomeric mixture of 8 and its C-7 epimer 9, in a ratio $8 / 9=9: 1$ (by $1 \mathrm{H}$ NMR spectroscopy). This mixture was subjected to column chromatography [35-70 $\mu \mathrm{m}$ silica gel $(11 \mathrm{~g})$, hexane/EtOAc mixtures]. On elution with hexane/EtOAc, 3:2 to 1:1, a stereoisomeric mixture of 8 and $9(168 \mathrm{mg})$, in a ratio $8 / 9=9: 1$, was obtained. By heating this solid in refluxing EtOAc $(0.5 \mathrm{~mL})$, an analytical sample of $8(101 \mathrm{mg}, 32 \%)$ was obtained as a white solid. m.p. $118-120^{\circ} \mathrm{C}$ (EtOAc). Rf (silica gel, $10 \mathrm{~cm}$, hexane/ EtOAc, 3:7): 0.28. IR (ATR): $v^{\sim}=3488(\mathrm{~m}), 3426$ (m), $2954(\mathrm{w}), 2903(\mathrm{w}), 2871(\mathrm{w}), 1721(\mathrm{~s}), 1439(\mathrm{~m}), 1325(\mathrm{~s}), 1217(\mathrm{~s}), 1196(\mathrm{~s}), 1170(\mathrm{~s}), 1156(\mathrm{~s})$, 1064 (s), 1037 (s), 1016 (s), 1000 (m), 926 (m), 888 (m), 730 (s), 658 (m) cm-1. C13H16O6 (268.26): C 58.20, H 6.01; found C 58.20, H 6.14. HRMS: calcd. for [C13H16O6 +Na]+ 291.0839; found 291.0841. 1H NMR: $\delta=1.59$ (s, $1 \mathrm{H}, \mathrm{OH}), 2.74(\mathrm{~s}, 1 \mathrm{H}, 7-\mathrm{H}), 3.07-3.09(\mathrm{~m}, 1 \mathrm{H}, 6 \mathrm{a}-\mathrm{H}), 3.19-3.21(\mathrm{~m}, 1 \mathrm{H}, 4-\mathrm{H})$, 3.62 (br. d, J = 9.0 Hz, $1 \mathrm{H}$ ) and 3.68 (br. d, J = 9.0 Hz, $1 \mathrm{H}, \mathrm{CH} 2 \mathrm{OH}$ ), 3.70 (s, $3 \mathrm{H}, \mathrm{C}-1-\mathrm{COOCH} 3$ ), $3.81(\mathrm{~s}, 3 \mathrm{H}, \mathrm{C}-7-\mathrm{COOCH} 3), 3.96(\mathrm{~d}, \mathrm{~J}=8.8 \mathrm{~Hz}, 1 \mathrm{H})$ and $4.00(\mathrm{~d}, \mathrm{~J}=8.8 \mathrm{~Hz}, 1 \mathrm{H}, 3-\mathrm{Ha}$ and $3-\mathrm{Hb})$, $5.93-5.95(\mathrm{ddd}, \mathrm{J}=5.8, \mathrm{~J}=3.0, \mathrm{~J}=1.0 \mathrm{~Hz}, 1 \mathrm{H}, 6-\mathrm{H}), 6.39-6.42(\mathrm{dd}, \mathrm{J}=5.8, \mathrm{~J}=3.0 \mathrm{~Hz}, 1 \mathrm{H}, 5-$ 
H) ppm. 13C NMR: $\delta=48.0(\mathrm{CH}, \mathrm{C}-4), 52.2(\mathrm{CH} 3, \mathrm{C}-1-\mathrm{COOCH} 3), 52.6(\mathrm{CH} 3, \mathrm{C}-7-\mathrm{COOCH} 3), 56.9$ (CH, C-6), 139.8 (CH, C-5), 170.9 (C, C-7-COOMe), 171.1 (C, C-1-COOMe) ppm. NMR spectroscopic data of 9: A mixture of 8 and $9(120 \mathrm{mg})$ in a ratio of ca. 1.5:10 was obtained by silica gel column chromatography as part of an operation to prepare diol 13 (see below). The NMR spectroscopic data for 9 are given based on this mixture. 1H NMR: $\delta=1.53$ (br. s, $1 \mathrm{H}, \mathrm{OH}), 3.02-3.04(\mathrm{~m}, 1 \mathrm{H}, 6 \mathrm{a}-\mathrm{H}), 3.12-$ 3.15 (m, $1 \mathrm{H}, 4-\mathrm{H}), 3.34$ (d, J = 4.4 Hz, $1 \mathrm{H}, 7-\mathrm{H}), 3.57$ (s, $3 \mathrm{H}, \mathrm{C}-1-\mathrm{COOMe}$ ), 3.61 (br. d, J = 11.2 Hz, 1 $\mathrm{H}$ ) and 3.69 (br. d, J = 11.2 Hz, $1 \mathrm{H}, \mathrm{CH} 2 \mathrm{OH}), 3.77$ (s, $3 \mathrm{H}, \mathrm{C}-7-\mathrm{COOMe}), 3.82(\mathrm{~d}, \mathrm{~J}=9.0 \mathrm{~Hz}, 1 \mathrm{H})$ and $3.98(\mathrm{~d}, \mathrm{~J}=9.0 \mathrm{~Hz}, 1 \mathrm{H}, 3-\mathrm{Ha}$ and $3-\mathrm{Hb}), 6.10(\mathrm{ddd}, \mathrm{J}=5.6, \mathrm{~J}=3.2, \mathrm{~J}=0.8 \mathrm{~Hz}, 1 \mathrm{H}, 6-\mathrm{H}), 6.16$ $(\mathrm{dd}, \mathrm{J}=5.6, \mathrm{~J}=2.8 \mathrm{~Hz}, 1 \mathrm{H}, 5-\mathrm{H}) \mathrm{ppm} .13 \mathrm{C} \mathrm{NMR:} \delta=49.0(\mathrm{CH}, \mathrm{C}-4), 51.7(\mathrm{CH} 3, \mathrm{C}-1-\mathrm{COOCH} 3)$, 52.3 (CH3, C-7-COOCH3), 55.8 (CH, C-6a), 55.9 (CH, C-7), $59.4(\mathrm{CH} 2, \mathrm{CH} 2 \mathrm{OH}), 68.2(\mathrm{CH} 2, \mathrm{C}-3)$, 73.1 (C, C- 3a), 88.8 (C, C-1), 129.6 (CH, C-6), 135.7 (CH, C-5), 169.3 (C, C-7-COOMe), 169.7 (C, C1-COOMe) ppm. Dimethyl (1RS,3aRS,4SR,6aSR,7SR)-3a-\{[(Methylsulfonyl)-oxy]methyl $\}-3,3 a, 4,6 a-$ tetrahydro-1H-1,4-methanocyclopenta[c]-furan-1,7-dicarboxylate (10): Methanesulfonyl chloride (0.03 $\mathrm{mL}, 0.36 \mathrm{mmol})$ was added dropwise to a cold $\left(0^{\circ} \mathrm{C}\right.$, ice/water bath) and magnetically stirred solution of alcohol $8(80 \mathrm{mg}, 0.3 \mathrm{mmol})$ and anhydrous Et3N $(0.1 \mathrm{~mL}, 0.69 \mathrm{mmol})$ in $\mathrm{CH} 2 \mathrm{Cl} 2(3.3 \mathrm{~mL})$ under an $\mathrm{Ar}$ atmosphere. The mixture was stirred at this temperature for $2 \mathrm{~h}$. Saturated aqueous NaHCO3 $(1 \mathrm{~mL})$ was then added. The organic phase was separated, and was washed with saturated aqueous NaHCO3 $(3 \rrbracket 3 \mathrm{~mL})$. The combined aqueous phases were extracted with CH2Cl2 $(3 \square 5 \mathrm{~mL})$. The combined organic phase and extracts were washed with water $(3 \mathrm{~mL})$ and brine $(3 \mathrm{~mL})$, dried (anhydrous $\mathrm{Na} 2 \mathrm{SO} 4)$, and concentrated in vacuo to give a solid residue $(101 \mathrm{mg})$ that was subjected to column chromatography [35-70 $\mu \mathrm{m}$ silica gel $(1.0 \mathrm{~g})$, hexane/EtOAc]. On elution with hexane/EtOAc, 7:3, mesylate 10 (87 mg, $85 \%$ ) was obtained as a white solid. m.p. $144-145^{\circ} \mathrm{C}$ (hexane/EtOAc). $\mathrm{Rf}$ (silica gel, $10 \mathrm{~cm}$, hexane/EtOAc, 1:4): 0.45. IR (ATR): $v^{\sim}=2960(\mathrm{w}), 2923(\mathrm{w}), 2901(\mathrm{w}), 2850(\mathrm{w}), 1731(\mathrm{~s})$, 1462 (w), 1439 (m), 1346 (s), 1338 (s), 1329 (s), 1224 (s), 1084 (s), 1172 (s), 1161 (s), 1066 (s), 956 (s), $938(\mathrm{~s}), 854$ (s), 836 (s), 742 (s), 729 (s) cm-1. C14H18O8S (346.35): C 48.55, H 5.24, S 9.26\%; found C 48.64, H 5.42, S 9.07\%. HRMS: calcd. for [C14H18NO8S + H]+ 347.0795; found 347.0793; calcd. For [C14H18NO8S + NH4]+ 364.1061; found 364.1060. 1H NMR: $\delta=2.79(\mathrm{~s}, 1 \mathrm{H}, 7-\mathrm{H}), 2.99(\mathrm{~s}, 3 \mathrm{H}$, CH3SO3), 3.14-3.16 (m, 1 H, 6a-H), 3.29-3.31 (m, 1 H, 4-H), 3.72 (s, 3 H, C-1-COOCH3), 3.83 (s, 3 $\mathrm{H}, \mathrm{C}-7-\mathrm{COOCH} 3), 3.94(\mathrm{~d}, \mathrm{~J}=8.8 \mathrm{~Hz}, 1 \mathrm{H})$ and $4.01(\mathrm{~d}, \mathrm{~J}=8.8 \mathrm{~Hz}, 1 \mathrm{H}, 3-\mathrm{Ha}$ and $3-\mathrm{Hb}), 4.23(\mathrm{~d}, \mathrm{~J}=$ $10.4 \mathrm{~Hz}, 1 \mathrm{H})$ and $4.30(\mathrm{~d}, \mathrm{~J}=10.4 \mathrm{~Hz}, 1 \mathrm{H}, \mathrm{CH} 2 \mathrm{OMs}), 5.99-6.02(\mathrm{ddd}, \mathrm{J}=5.8, \mathrm{~J}=3.0, \mathrm{~J}=0.8$ $\mathrm{Hz}, 1 \mathrm{H}, 6-\mathrm{H}), 6.44-6.46(\mathrm{dd}, \mathrm{J}=5.8, \mathrm{~J}=3.0 \mathrm{~Hz}, 1 \mathrm{H}, 5-\mathrm{H}) \mathrm{ppm} .13 \mathrm{C} \mathrm{NMR}: \delta=37.5(\mathrm{CH} 3$, CH3SO3), 48.3 (CH, C-4), 52.4 (CH3, C-1-COOCH3), 52.8 (CH3, C-7-COOCH3), 56.6 (CH, C-7), 59.3 (CH, C-6a), 66.2 (CH2, CH2OMs), 67.9 (CH2, C-3), 72.7 (C, C-3a), 85.4 (C, C-1), 128.4 (CH, C6), 139.5 (CH, C-5), 170.1 (C, C-7-COOCH3), 170.6 (C, C-1-COOCH3) ppm.

\section{Dimethyl (1RS,3aRS,4SR,6aSR,7SR)-3a-(Iodomethyl)-3,3a,4,6atetrahydro-1H-1,4-} methanocyclopenta[c]furan-1,7-dicarboxylate (11): Powdered $\mathrm{NaI}(347 \mathrm{mg}, 2.3 \mathrm{mmol}$ ) was added to a solution of mesylate $10(80 \mathrm{mg}, 0.23 \mathrm{mmol})$ in anhydrous acetone $(2.9 \mathrm{~mL})$, and the mixture was heated at reflux under Ar for $18 \mathrm{~h}$. The mixture was cooled to room temperature, and concentrated in vacuo. The solid residue was subjected to column chromatography [35-70 $\mu \mathrm{m}$ silica gel $(1.0 \mathrm{~g})$, hexane/EtOAc mixtures]. On elution with hexane/EtOAc, 96:4, iodide $11(78 \mathrm{mg}, 90 \%)$ was isolated as a pale yellow oil. Rf (silica gel, $10 \mathrm{~cm}$, hexane/EtOAc, 3:7): 0.54. IR (ATR): $v^{\sim}=2949(\mathrm{w}), 2889(\mathrm{w})$, $2843(\mathrm{w}), 1731$ (s), 1435 (m), $1326(\mathrm{~m}), 1257$ (m), 1217 (s), 1189 (s), 1164 (s), $1102(\mathrm{~m}), 1069$ (s), 1000 (m), 728 (s) cm-1. C13H15IO5 (378.16): C 41.29, H 4.00; I $33.56 \%$; found C 41.43, H 4.14; I 33.30\%. HRMS: calcd. for [C13H15IO5 + H] +379.0037; found 379.0033; calcd. for [C13H15IO5 + $\mathrm{Na}]+400.9856$; found 400.9856. $1 \mathrm{H} \mathrm{NMR:} \delta=2.73$ (s, $1 \mathrm{H}, 7-\mathrm{H}), 3.06-3.09$ (br. s, $1 \mathrm{H}, 6 \mathrm{a}-\mathrm{H}), 3.23(\mathrm{~d}, \mathrm{~J}$ $=10.4 \mathrm{~Hz}, 1 \mathrm{H})$ and $3.27(\mathrm{~d}, \mathrm{~J}=10.4 \mathrm{~Hz}, 1 \mathrm{H}, \mathrm{CHaI}$ and $\mathrm{CHbI}), 3.32-3.35$ (br. s, $1 \mathrm{H}, 4-\mathrm{H}), 3.71(\mathrm{~s}, 3 \mathrm{H}$, C-1-COOCH3), 3.81 (s, $3 \mathrm{H}, \mathrm{C}-7-\mathrm{COOCH} 3), 3.89(\mathrm{~d}, \mathrm{~J}=8.8 \mathrm{~Hz}, 1 \mathrm{H})$ and $3.98(\mathrm{~d}, \mathrm{~J}=8.8 \mathrm{~Hz}, 1 \mathrm{H}, 3-$ $\mathrm{Ha}$ and 3-Hb), 5.98-6.01 (ddd, $\mathrm{J}=5.6, \mathrm{~J}=2.8, \mathrm{~J}=1.2 \mathrm{~Hz}, 1 \mathrm{H}, 6-\mathrm{H}), 6.45-6.47(\mathrm{ddm}, \mathrm{J}=5.6, \mathrm{~J}$ 
$=3.0 \mathrm{~Hz}, 1 \mathrm{H}, 5-\mathrm{H}) \mathrm{ppm} .13 \mathrm{C}$ NMR: $\delta=3.4(\mathrm{CH} 2, \mathrm{CH} 2 \mathrm{I}), 50.1(\mathrm{CH}, \mathrm{C}-4), 52.3(\mathrm{CH} 3, \mathrm{C}-1-\mathrm{COOCH} 3)$, 52.7 (CH3, C-7-COOCH3), $57.2(\mathrm{CH}, \mathrm{C}-7), 62.6(\mathrm{CH}, \mathrm{C}-6 \mathrm{a}), 70.9(\mathrm{CH} 2, \mathrm{C}-3), 73.8(\mathrm{C}, \mathrm{C}-3 \mathrm{a}), 85.5(\mathrm{C}$, $\mathrm{C}-1), 127.9$ (CH, C-6), 139.6 (CH, C-5), 170.5 (C, C-7-COOCH3), 170.6 (C, C-1-COOCH3) ppm.

Dimethyl (3RS,4SR,4aSR,5SR,5aRS,8SR,8aRS,9aRS, 10SR,11RS)-4a,5,5a,8,8a,9-Hexahydro-1H-
3,9a,5,8-(epiethane[1,1,- 2,2] tetrayl)cyclopenta[g]isochromene-3,4(4H)-dicarboxylate (12): In a 10 $\mathrm{mL}$ flask, $\mathrm{KH}(30 \%$ in mineral oil; $67 \mathrm{mg}, 0.50 \mathrm{mmol})$ was washed with anhydrous THF $(5 \square 1 \mathrm{~mL})$ under an Ar atmosphere. Anhydrous THF (1 mL) was added to the washed KH, and the resulting suspension was cooled to $0{ }^{\circ} \mathrm{C}$ in an ice/water bath. Freshly distilled cyclopentadiene ( $50 \mu \mathrm{L}, 36 \mathrm{mg}$, $0.54 \mathrm{mmol}$ ) was added, and the mixture was stirred at this temperature for $10 \mathrm{~min}$. 18-Crown-6 $(7 \mathrm{mg}$, $26 \mu \mathrm{mol}$, ca. $5 \%$ relative to $\mathrm{KH}$ ) was added, and the mixture was stirred at $0{ }^{\circ} \mathrm{C}$ for $10 \mathrm{~min}$, and at room temperature for $15 \mathrm{~min}$ to give a pinkish-colored suspension. In a $25 \mathrm{~mL}$ flask equipped with a magnetic stirrer bar and reflux condenser, under an Ar atmosphere, a solution of iodide $11(50 \mathrm{mg}, 0.13 \mathrm{mmol})$ in anhydrous DMF $(0.8 \mathrm{~mL})$ was prepared. The solution was cooled to $0{ }^{\circ} \mathrm{C}$ in an ice/water bath and then, part of the above solution of potassium cyclopentadienide $(0.5 \mathrm{~m} ; 0.27 \mathrm{~mL}, 0.13 \mathrm{mmol})$ was added dropwise. The mixture was stirred at $0{ }^{\circ} \mathrm{C}$ for $5 \mathrm{~min}$, and at room temperature for $10 \mathrm{~min}$, and then it was heated to $90^{\circ} \mathrm{C}$ for $17 \mathrm{~h}$. The mixture was cooled to room temperature, $\mathrm{MeOH}(10 \mu \mathrm{L})$ was added, and the mixture was stirred for $10 \mathrm{~min}$. Then, EtOAc $(5 \mathrm{~mL})$ and water $(5 \mathrm{~mL})$ were added, and the organic phase was separated. The aqueous phase was extracted with EtOAc (4! $5 \mathrm{~mL})$. The combined organic phases were washed with saturated aqueous NaHCO3 $(3 \square 5 \mathrm{~mL})$, water $(2 \square 5 \mathrm{~mL})$, and brine $(5 \mathrm{~mL})$, dried (anhydrous Na2SO4), and concentrated in vacuo to give crude diester $12(45 \mathrm{mg})$ as a brown oil. This crude product was subjected to column chromatography [35-70 $\mu \mathrm{m}$ silica gel $(1.3 \mathrm{~g})$, hexane/EtOAc mixtures] to give, on elution with hexane/ EtOAc, 94:6, diester $12(25 \mathrm{mg}, 60 \%)$ as a white solid. Crystallization of the above product from $\mathrm{CH} 2 \mathrm{Cl} 2 /$ pentane gave an analytical sample of 12 as a white solid. m.p. $160-161{ }^{\circ} \mathrm{C}$. Rf (silica gel, $10 \mathrm{~cm}$, hexane/EtOAc, 3:7): 0.72. IR (ATR): $v^{\sim}=2971$ (w), $2954(\mathrm{~m}), 2928(\mathrm{~m}), 2892(\mathrm{w}), 2852(\mathrm{w}), 1755(\mathrm{~s}), 1728(\mathrm{~s}), 1426(\mathrm{~m}), 1349(\mathrm{~m}), 1207$ (s), $1188(\mathrm{~s})$, $1164(\mathrm{~s}), 1072(\mathrm{~s}), 1042(\mathrm{~s}), 973(\mathrm{~m}), 932(\mathrm{~m}), 739$ (s), $698(\mathrm{~m}) \mathrm{cm}-1 . \mathrm{C} 18 \mathrm{H} 20 \mathrm{O} 5 \cdot 1 / 3 \mathrm{H} 2 \mathrm{O}$ (322.36): C 67.07, H 6.46\%; found C 66.79, H 6.23\%. HRMS: calcd. for [C18H20O5 + Na]+339.1203; found 339.1205. 1H NMR: $\delta=1.62(\mathrm{dd}, \mathrm{J}=13.8, \mathrm{~J}=3.0 \mathrm{~Hz}, 1 \mathrm{H}, 9-\mathrm{Ha}), 1.68$ (br. d, J = 6.0 Hz, $1 \mathrm{H}, 5-\mathrm{H})$, $1.76(\mathrm{dd}, \mathrm{J}=14.0, \mathrm{~J}=2.8 \mathrm{~Hz}, 1 \mathrm{H}, 9-\mathrm{Hb}), 1.92-1.95(\mathrm{~m}, 1 \mathrm{H}, 8 \mathrm{a}-\mathrm{H}), 2.03$ (br. d, J $=5.6 \mathrm{~Hz}, 1 \mathrm{H}, 11-$ H), $2.06(\mathrm{~d}, \mathrm{~J}=1.6 \mathrm{~Hz}, 1 \mathrm{H}, 10-\mathrm{H}), 2.42-2.44$ (br. s, $2 \mathrm{H}, 4 \mathrm{a}-\mathrm{H}$ and 8-H), 2.49-2.51 (br. s, $1 \mathrm{H}, 5 \mathrm{a}-\mathrm{H})$, 2.79 (s, $1 \mathrm{H}, 4-\mathrm{H}), 3.66$ (s, $3 \mathrm{H}, \mathrm{C}-3-\mathrm{COOCH} 3), 3.70$ (d, J = 7.6 Hz, $1 \mathrm{H}, 1-\mathrm{Ha}), 3.81$ (s, $3 \mathrm{H}, \mathrm{C}-4-$ COOCH3), $3.92(\mathrm{dd}, \mathrm{J}=7.6, \mathrm{~J}=0.8 \mathrm{~Hz}, 1 \mathrm{H}, 1-\mathrm{Hb}$ ), 6.07 (pseudo $\mathrm{t}, \mathrm{J}=1.8 \mathrm{~Hz}, 2 \mathrm{H}, 6-\mathrm{H}$ and 7-H) ppm. 13C NMR: $\delta=28.5$ (CH2, C-9), 38.5 (CH, C-11), 46.3 (CH, C-4a), 47.9 (CH, C-5), 49.0 (CH, C5a), $49.4(\mathrm{CH}, \mathrm{C}-8), 52.0$ (CH3, C-3-COOCH3), 52.3 (CH3, C-4-COOCH3), $52.4(\mathrm{CH}, \mathrm{C}-8 \mathrm{a}), 53.3(\mathrm{C}$, C-9a), $56.6(\mathrm{CH}, \mathrm{C}-4), 59.5(\mathrm{CH}, \mathrm{C}-10), 71.9(\mathrm{CH} 2, \mathrm{C}-1), 88.0$ (C, C-3), $136.3(\mathrm{CH}, \mathrm{C}-7), 136.8(\mathrm{CH}$, C-6), 170.4 (C, C-3- COOCH3), 171.5 (C, C-4-COOCH3) ppm.

\footnotetext{
Dimethyl (1R,4S)-7,7-Bis(iodomethyl)bicyclo[2.2.1]hepta-2,5-diene-2,3-dicarboxylate (15) (a) Mixture of Alcohol 8, its C-7 Epimer, and Dimethyl (1R,4S)-7,7Bis(hydroxymethyl)bicyclo[2.2.1] hepta-2,5-diene-2,3-dicarboxylate (13): pTsOH·H2O (144 mg, $0.76 \mathrm{mmol})$ was added to a solution of diacetate $7(1.34 \mathrm{~g}, 3.80 \mathrm{mmol})$ in anhydrous $\mathrm{MeOH}(13.5 \mathrm{~mL})$, and the resulting solution was heated under reflux for $6.5 \mathrm{~h}$. The solution was cooled to room temperature, and the solvent was removed under vacuum. The residue was dissolved in $\mathrm{CH} 2 \mathrm{Cl} 2$ ( 30 $\mathrm{mL})$. This solution was washed with saturated aqueous NaHCO3 solution $(2 \square 8 \mathrm{~mL})$ and brine $(10 \mathrm{~mL})$, dried (anhydrous Na2SO4), and concentrated in vacuo to give a mixture of diol 13 and tricyclic alcohols8 and 9, approximate ratio 13/8/9 20:12:5 by 1H NMR spectroscopy (by integration of the olefinic signals) $(837 \mathrm{mg}$ ) as a yellow oil, which was used as such in the next step. The combined aqueous washings were extracted with $\mathrm{CH} 2 \mathrm{Cl} 2(3 \square 20 \mathrm{~mL})$. These combined organic extracts were
} 
washed with brine $(10 \mathrm{~mL})$, dried (anhydrous $\mathrm{Na} 2 \mathrm{SO} 4)$, and concentrated in vacuo to give an orange oily residue $(120 \mathrm{mg})$. This was a mixture of diol 13 and a stereoiso meric mixture of tricyclic alcohols 8 and 9 , approximate ratio 13/8/9 10:1.3:1 by $1 \mathrm{H}$ NMR spectroscopy.

(b) Mixture of Mesylate 10, its C-7 Epimer, and Dimethyl (1R,4S)-7,7Bis(methylsulfonyloxymethyl)bicyclo[2.2.1] hepta-2,5-diene-2,3-dicarboxylate (14): Methanesulfonyl chloride $(0.6 \mathrm{~mL}, 7.5 \mathrm{mmol})$ was added dropwise to a cold $\left(0^{\circ} \mathrm{C}\right.$, ice/water bath $)$ and magnetically stirred solution of a mixture of diol 13 and alcohols 8 and $9(837 \mathrm{mg}$, approximate ratio 13/8/9 20:12:5, $1.69 \mathrm{mmol} 13,1.43 \mathrm{mmol} 8+9)$ and anhydrous Et3N $(1.7 \mathrm{~mL}, 12.5 \mathrm{mmol})$ in anhydrous $\mathrm{CH} 2 \mathrm{Cl} 2(34 \mathrm{~mL})$ under an Ar atmosphere. The mixture was stirred at this temperature for $1.5 \mathrm{~h}$. Saturated aqueous NaHCO3 $(2.5 \mathrm{~mL})$ was added, and the organic phase was separated, and washed with saturated aqueous $\mathrm{NaHCO} 3(3[10 \mathrm{~mL}$ ). The combined aqueous phases were extracted with $\mathrm{CH} 2 \mathrm{Cl} 2$ (3] $20 \mathrm{~mL})$. The combined organic phase and extracts were washed with water $(15 \mathrm{~mL})$ and brine $(15$ $\mathrm{mL}$ ), dried (anhydrous Na2SO4), and concentrated in vacuo to give a mixture of dimesylate 14 and the tricyclic mesylates 10 and its C-7 epimer $(1.15 \mathrm{~g})$ as an orange oil.

(c) Dimethyl (1R,4S)-7,7-Bis(iodomethyl)bicyclo[2.2.1] hepta-2,5-diene-2,3-dicarboxylate (15): Powdered NaI ( $4.86 \mathrm{~g}, 32.4 \mathrm{mmol})$ was added to a solution of dimesylate 14 and monomesylates 10 and its C-7 epimer ( $1.15 \mathrm{~g}, 1.60 \mathrm{mmol} 14$ and $1.36 \mathrm{mmol} 10+\mathrm{C}-7$ epimer) in anhydrous acetone $(36 \mathrm{~mL})$. The mixture was heated under reflux for $16 \mathrm{~h}$. The mixture was then cooled to room temperature, and the solvent was removed under reduced pressure. The resulting yellow solid residue $(6.1 \mathrm{~g})$ was subjected to column chromatography [silica gel 35-70 $\mu \mathrm{m}(20 \mathrm{~g})$, hexane/EtOAc mixtures] to give, on elution with hexane/EtOAc, 97.5:2.5, diiodide $15(574 \mathrm{mg}, 31 \%$ from diacetate 7$)$ as a yellow oil, and on elution with hexane/ EtOAc, 85:15, a stereoisomeric mixture of iodides 11 and its C-7 epimer (404 $\mathrm{mg}, 28 \%$ from diacetate 7 ) as a pale yellow oil.

Analytical and spectroscopic data for 15: Rf (silica gel, $10 \mathrm{~cm}$, hexane/ EtOAc, 3:7): 0.62. IR (ATR): v $=2998(\mathrm{~m}), 2950(\mathrm{~m}), 2849(\mathrm{w}), 1731(\mathrm{~s}), 1713(\mathrm{~s}), 1629(\mathrm{~m}), 1434(\mathrm{~s}), 1324(\mathrm{~s}), 1281(\mathrm{~s}), 1255(\mathrm{~s})$, $1222(\mathrm{~s}), 1202(\mathrm{~s}), 1165(\mathrm{~m}), 1100(\mathrm{~s}), 1053(\mathrm{~m}), 821(\mathrm{~m}), 778(\mathrm{~m}), 762(\mathrm{~m}), 732(\mathrm{~m}), 643(\mathrm{~m}) \mathrm{cm}-1$. HRMS: calcd. for [C13H14I2O4 + H] + 488.9054; found 488.9051; calcd. for [C13H14I2O + $\mathrm{Na}]+510.8874$; found 510.8864. 1H NMR: $\delta=3.716$ (br. s, $2 \mathrm{H}$, syn-CH2I), 3.720 (br. s, $2 \mathrm{H}$, antiCH2I), 3.81 [s, $6 \mathrm{H}, \mathrm{C}-2(3)-\mathrm{COOCH} 3$ ], 3.84 [t, J = 2.0 Hz, $2 \mathrm{H}, 1(4)-\mathrm{H}$ ], 6.92 [pseudo t, J = 2.0 Hz, 2 $\mathrm{H}, 5(6)-\mathrm{H}] \mathrm{ppm}$. NOESY: irradiation at $\delta=6.92[5(6)-\mathrm{H}] \mathrm{ppm}$ shows an NOE with the protons at $\delta=$ 3.84 [1(4)-H] and 3.716 (syn-CH2I) ppm. 13C NMR: $\delta=11.5$ (CH2I), 12.3 (CH2I), 52.3 (CH3, 2 COOCH3), 60.7 [CH, C-1(4)], 87.2 (C, C-7), 141.1 [CH, C-5(6)], 150.0 [C, C-2(3)], 164.6 [C, C-2(3)$\mathrm{COOCH} 3] \mathrm{ppm}$.

\section{Dimethyl (1R,3aS,4R,4aR,4bS,5R,8S,8aR,9S,9as,10as,11s,13S)-1,3a,4a,4b,5,8,8a,9,10,10a-} Decahydro-4H-5,8,9a-(epiethane[1,1,2]-triyl)-1,4,9-(epimethanetriyl)cyclopenta[b]fluorene-4,13dicarboxylate(16): In a $10 \mathrm{~mL}$ flask, $\mathrm{KH}(30 \%$ in mineral oil; $134 \mathrm{mg}, 1.0 \mathrm{mmol})$ was washed with anhydrous THF (5马 $2 \mathrm{~mL})$ under an Ar atmosphere. Anhydrous THF $(2 \mathrm{~mL})$ was added to the washed $\mathrm{KH}$, and the suspension was cooled to $0{ }^{\circ} \mathrm{C}$ in an ice/water bath. Freshly distilled cyclopentadiene $(0.1$ $\mathrm{mL}, 73 \mathrm{mg}, 1.1 \mathrm{mmol}$ ) was added, and the mixture was stirred at this temperature for $10 \mathrm{~min}$. 18-Crown$6(13 \mathrm{mg}, 50 \mu \mathrm{mol}, 5 \mathrm{~mol}-\%$ relative to $\mathrm{KH})$ was added, and the mixture was stirred at $0{ }^{\circ} \mathrm{C}$ for $10 \mathrm{~min}$, and then at room temperature for $15 \mathrm{~min}$. A solution of diiodide $15(83 \mathrm{mg}, 0.17 \mathrm{mmol})$ in anhydrous DMF $(1 \mathrm{~mL})$ was prepared in a $10 \mathrm{~mL}$ flask equipped with a magnetic stirrer bar and a reflux condenser, under an Ar atmosphere. The solution was cooled to $0{ }^{\circ} \mathrm{C}$ in an ice/water bath, and then part of the above solution of potassium cyclopentadienide $(0.5 \mathrm{~m} ; 0.75 \mathrm{~mL}, 0.37 \mathrm{mmol})$ was added dropwise. The 
mixture was stirred at $0{ }^{\circ} \mathrm{C}$ for $5 \mathrm{~min}$, and at room temperature for $10 \mathrm{~min}$, and then it was heated to 90 ${ }^{\circ} \mathrm{C}$ for $17 \mathrm{~h}$. The mixture was cooled to room temperature, then $\mathrm{MeOH}(20 \mu \mathrm{L})$ was added, and the mixture was stirred for $10 \mathrm{~min}$. Then, EtOAc $(5 \mathrm{~mL})$ and water $(5 \mathrm{~mL})$ were added and the organic phase was separated. The aqueous phase was extracted with EtOAc $(4 \square 15 \mathrm{~mL})$. The combined organic phases were washed with saturated aqueous NaHCO3 $(3 \square 5 \mathrm{~mL})$, water $(2 \square 8 \mathrm{~mL})$ and brine $(8 \mathrm{~mL})$, dried (anhydrous Na2SO4), and concentrated in vacuo to give crude diester $16(73 \mathrm{mg})$ as a brown paste. This material was subjected to column chromatography [35-70 $\mu \mathrm{m}$ silica gel $(1.5 \mathrm{~g})$, hexane/EtOAc mixtures] to give, on elution with hexane/EtOAc, 99:1 to 95:5, diester 16 (30 mg, 49\%) as a pale yellow oil. By treating this oil with Et2O, and washing the solid thus formed with pentane, an analytical sample of 16 was obtained as a pale grey solid. m.p. $92.5-94{ }^{\circ} \mathrm{C}$. Rf (silica gel, $10 \mathrm{~cm}$, hexane/EtOAc, 3:7): 0.50. IR (ATR): $v^{\sim}=3055$ (w), $2944(\mathrm{~m}), 2912(\mathrm{~m}), 2842(\mathrm{~m}), 1745$ (s), 1727 (s), $1432(\mathrm{~m}), 1315(\mathrm{~m}), 1256$ (s), 1241 (s), 1224 (s), 1152 (s), 1141 (s), 1106 (s), 1070 (s), 1038 (s), 1028 (s), $1010(\mathrm{~s}), 741(\mathrm{~m}), 709(\mathrm{~s}), 665(\mathrm{~m}) \mathrm{cm}-1 . \mathrm{C} 23 \mathrm{H} 24 \mathrm{O} 4 \cdot 1 / 3 \mathrm{H} 2 \mathrm{O}$ (370.45): C 74.57, H 6.71\%; found C 74.63, H 7.00\%. HRMS: calcd. for [C23H24O4 + H]+365.1747; found 365.1754. 1H NMR: $\delta=1.49$ (d, J = 2.8 Hz, 2 H, 12-H2), 1.54 (d, J = 2.8 Hz, 2 H, 10-H2), 1.78-1.82 (m, $1 \mathrm{H}, 11-\mathrm{H}), 1.83$ [s, $2 \mathrm{H}$, 4a(9)-H], 1.92-1.95 (m, 1 H, 10a-H), 1.98 [s, 2 H, 4b(8a)-H], 2.38-2.40 [m, 2 H, 5(8)-H], 2.69-2.71 [m, $2 \mathrm{H}, 1(3 \mathrm{a})-\mathrm{H}], 3.59$ [s, $6 \mathrm{H}, \mathrm{C}-4(13)-\mathrm{COOCH} 3], 6.03$ [t, J = $1.8 \mathrm{~Hz}, 2 \mathrm{H}, 6(7)-\mathrm{H}], 6.15$ [t, J = $1.8 \mathrm{~Hz}, 2$ H, 2(3)-H] ppm. 13C NMR: $\delta=34.3(\mathrm{CH} 2, \mathrm{C}-10), 35.2(\mathrm{CH} 2, \mathrm{C}-12), 42.27$ [CH2, C-4a(9)], $42.34(\mathrm{C}$, C-9a), 49.3 [CH, C- 5(8)], 51.2 [CH3, C-4(13)-COOCH3], 51.9 (CH, C-11), 53.5 (CH, C-10a), 54.7 [CH, C-4a(9)], 54.8 [CH, C-1(3a)], 64.6 [C, C-4(13)], 137.2 [CH, C-6(7)], 137.4 [CH, C-2(3)], 172.4 [C, $\mathrm{C}-4(13)-\mathrm{COOCH} 3] \mathrm{ppm}$.

X-ray Crystal-Structure Determination of Compound 8: A colorless prism-like specimen of C13H16O6, approximate dimensions $0.228 \mathrm{~mm} \square 0.427 \mathrm{~mm} \square 0.578 \mathrm{~mm}$, was used for the X-ray crystallographic analysis. The X-ray intensity data were measured with a D8 Venture system equipped with a Multilayer monochromator and a Mo microfocus $(\lambda=1.54178 \AA)$. A total of 4683 frames were collected. The total exposure time was $26.02 \mathrm{~h}$. The frames were integrated with the Bruker SAINT software package using a narrow- frame algorithm. The integration of the data using a monoclinic unit cell yielded a total of 13259 reflections to a maximum $\theta$ angle of $72.20^{\circ}(0.81 \AA$ resolution $)$, of which 4742 were independent (average redundancy 2.796 , completeness: $98.7 \%$, Rint $=3.42 \%$, Rsig $=3.56$ $\%$ ), and $4718(99.49 \%)$ were greater than $2 \sigma(\mathrm{F} 2)$. The final cell constants of $\mathrm{a}=5.8773(8) \AA, \mathrm{b}=$ $30.253(4) \AA, c=7.0235(9) \AA, \beta=100.153(3)^{\circ}, V=1229.3(3) \AA 3$, are based on the refinement of the XYZ-centroids of 120 reflections above $20 \sigma(\mathrm{I})$ with $\left.21.75^{\circ}\right] 2 \theta \quad 116.5^{\circ}$. Data were corrected for absorption effects using the multi-scan method (SADABS). The calculated minimum and maximum transmission coefficients (based on crystal size) are 0.6325 and 0.7536 . The structure was solved using the Bruker SHELXTL software package, and refined using SHELXL[18] and the space group P21, with $\mathrm{Z}=4$ for the formula unit, $\mathrm{C} 13 \mathrm{H} 16 \mathrm{O}$. The final anisotropic full-matrix least-squares refinement on $\mathrm{F} 2$ with 353 variables converged at $\mathrm{R} 1=3.18 \%$, for the observed data and $\mathrm{wR} 2=8.72 \%$ for all data. The goodnessof- fit was 1.051 . The largest peak in the final difference electron density synthesis was 0.278 e $\AA-3$ and the largest hole was -0.218 e $\AA-3$ with an RMS deviation of 0.044 e $\AA-3$. On the basis of the final model, the calculated density was $1.449 \mathrm{gcm}-3$ and $\mathrm{F}(000), 568$ e (Table 1).

X-ray Crystal-Structure Determination of Compound 12: A colorless prism-like specimen of C18H20O5, approximate dimensions $0.222 \mathrm{~mm} \square 0.308 \mathrm{~mm} \square 0.554 \mathrm{~mm}$, was used for the X-ray crystallographic analysis. The X-ray intensity data were measured with a D8 Venture system equipped with a multilayer monochromator and a Mo microfocus $(\lambda=0.71073 \AA)$. The frames were integrated with the Bruker SAINT software package using a Narror-frame algorithm. The integration of the data using a triclinic unit cell yielded a total of 15320 reflections to a maximum $\theta$ angle of $26.45^{\circ}(0.80 \AA$ resolution), of which 3007 were independent (average redundancy 5.095, completeness: $99.6 \%$, Rint $=$ 
$2.06 \%$, Rsig $=1.39 \%)$, and $2847(94.68 \%)$ were greater than $2 \sigma(\mathrm{F} 2)$. The final cell constants of $\mathrm{a}=$ 9.1711(3) $\AA, b=9.8643(4) \AA, c=10.2303(4) \AA, \alpha=66.5310(10)^{\circ}, \beta=64.5980(10)^{\circ}, \gamma=65.2720(10)^{\circ}$, $\mathrm{V}=731.86(5) \AA 3$, are based on the refinement of the XYZ-centroids of reflections above $20 \sigma(\mathrm{I})$. Data were corrected for absorption effects using the multi-scan method (SADABS). The calculated minimum and maximum transmission coefficients (based on crystal size) are 0.6847 and 0.7454 . The structure was solved using the Bruker SHELXTL software package, and refined using SHELXL[18] and the space group $\mathrm{P}^{-}$, with $\mathrm{Z}=2$ for the formula unit, $\mathrm{C} 18 \mathrm{H} 20 \mathrm{O} 5$. The final anisotropic full-matrix least-squares refinement on F2 with 210 variables converged at R1 $=3.85 \%$, for the observed data and $w R 2=10.47 \%$ for all data. The goodness-of-fit was 1.081. The largest peak in the final difference electron density synthesis was $0.323 \mathrm{e} \AA-3$ and the largest hole was $-0.292 \mathrm{e} \AA-3$ with an RMS deviation of $0.064 \mathrm{e} \AA-3$. On the basis of the final model, the calculated density was $1.435 \mathrm{~g} \mathrm{~cm}-3$ and $F(000), 336 \mathrm{e}$ (Table 1 ).

X-ray Crystal-Structure Determination of Compound 16: A colorless plate-like specimen of C23H24O4, approximate dimensions $0.096 \mathrm{~mm} \rrbracket 0.216 \mathrm{~mm} \rrbracket 0.285 \mathrm{~mm}$, was used for the X-ray crystallographic analysis. The X-ray intensity data were measured with a D8 Venture system equipped with a multilayer monochromator and a Mo microfocus $(\lambda=0.71073 \AA)$. The frames were integrated with the Bruker SAINT software package using a narrow-frame algorithm. The integration of the data using a monoclinic unit cell yielded a total of 46427 reflections to a maximum $\theta$ angle of $28.34^{\circ}(0.75 \AA$ resolution), of which 4298 were independent (average redundancy 10.802, completeness: $99.8 \%$, Rint $=$ $4.10 \%$, Rsig $=1.82 \%)$, and $3654(85.02 \%)$ were greater than $2 \sigma(\mathrm{F} 2)$. The final cell constants of $\mathrm{a}=$ 9.6672(4) $\AA, b=10.5955(5) \AA, c=17.0896(7) \AA, \beta=99.698(2)^{\circ}, V=1725.45(13) \AA 3$, are based on the refinement of the XYZ-centroids of reflections above $20 \sigma(\mathrm{I})$. Data were corrected for absorption effects using the multiscan method (SADABS). The calculated minimum and maximum transmission coefficients (based on crystal size) are 0.7050 and 0.7457 . The structure was solved using the Bruker SHELXTL Software Package, and refined using SHELXL[18] and the space group P21/c, with Z = 4 for the formula unit, $\mathrm{C} 23 \mathrm{H} 24 \mathrm{O} 4$. The final anisotropic full-matrix leastsquares refinement on F2 with 258 variables converged at $\mathrm{R} 1=3.95 \%$, for the observed data and $\mathrm{wR} 2=10.72 \%$ for all data. The goodnessof-fit was 1.047. The largest peak in the final difference electron density synthesis was $0.364 \mathrm{e} \AA-3$ and the largest hole was -0.265 e $\AA-3$ with an RMS deviation of 0.058 e $\AA-3$. On the basis of the final model, the calculated density was $1.403 \mathrm{gcm}-3$ and $\mathrm{F}(000), 776$ e (Table 1 ).

CCDC-1063995 (for 8), -1063996 (for 12), and 1063997 (for 16) contain the supplementary crystallographic data for this paper. These data can be obtained free of charge from The Cambridge Crystallographic Data Centre via www.ccdc.cam.ac.uk/data_request/cif. 


\section{ACKNOWLEDGEMENTS}

438

439 Financial support from Dirección General de Investigación of the Ministerio de Economía y

440 Competitividad (MINECO) (Project number CTQ2011-22433) is gratefully acknowledged. The authors

441 also thank the Centres Científics i Tecnològics of the University of Barcelona (CCiTUB) for NMR, MS,

442 and X-ray diffraction facilities, and the Institut de Química Avançada de Catalunya (IQAC, CSIC,

443 Barcelona) for carrying out the elemental analyses.

444 
[1] W. J. Geldenhuys, S. F. Malan, J. R. Bloomquist, A. P. Marchand, C. J. Van der Schyf, Med. Res. Rev. 2005, 25, 21-48.

[2] T. R. Bailey, S. R. Rippin, E. Opsitnick, C. J. Burns, D. C. Pevear, M. S. Collett, G. Rhodes, S. Tohan, J. W. Huggins, R. O. Baker, E. R. Kern, K. A. Keith, D. Dai, G. Yang, D. Hruby, R. Jordan, J. Med. Chem. 2007, 50, 1442-1444.

[3] D. W. Oliver, S. F. Malan, Med. Chem. Res. 2008, 17, 137-151.

[4] M. Rey-Carrizo, M. Barniol-Xicota, C. Ma, M. Frigole-Vivas, E. Torres, L. Naesens, S. Llabres, J. Juarez-Jimenez, F. J. Luque, W. F. De Grado, R. A. Lamb, L. H. Pinto, S. Vázquez, J. Med. Chem. 2014, 57, 5738-5747, and ref.[11-15] cited therein.

[5] P. Camps, T. Gómez, C. Monasterolo, J. Org. Chem. 2012, 77, 11270-11282.

[6] M. A. Gunawan, J. C. Hierso, D. Poinsot, A. A. Fokin, N. A. Fokina, B. A. Tkachenko, P. R. Schreiner, New J. Chem. 2014, 38, 28-41.

[7] S. R. Barua, H. Quanz, M. Olbrich, P. R. Schreiner, D. Trauner, W. D. Allen, Chem. Eur. J. 2014, 20, 1638-1645.

[8] M. Olbrich, P. Mayer, D. Trauner, Org. Biomol. Chem. 2014, 12, 108-112.

[9] M. D. Johnstone, E. K. Schwarze, G. H. Clever, F. M. Pfeffer, Chem. Eur. J. 2015, 21, 3948 3955.

[10] N. Beaulieu, P. Deslongchamps, Can. J. Chem. 1980, 58, 875-877.

[11] C. C. Oliveira, E. A. F. Dos Santos, J. H. B. Nunes, C. R. D. Correia, J. Org. Chem. 2012, 77, $8182-8190$

[12] J. Broggi, N. Joubert, S. Díez-González, S. Berteina-Raboin, T. Zevaco, S. P. Nolan, L. A. Agrofoglio, Tetrahedron 2009, 65, 1162-1170.

[13] F. G. Klärner, F. Adamsky, Chem. Ber. 1983, 116, $299-322$.

[14] R. W. Holdr, J. P. Daub, W. E. Baker, R. H. Gilbert III, N. A. Graf, J. Org. Chem. 1982, 47, $1445-1451$.

[15] E. Y.-J. Min, J. A. Byers, J. E. Bercaw, Organometallics 2008, 27, 2179-2188.

[16] E. Polo, F. Forlini, V. Bertolasi, A. C. Boccia, M. C. Sacchi, Adv. Synth. Catal. 2008, 350, $1544-1556$.

[17] A. Bader, K. Ebel, N. Skuballa, Chem. Ber. 1988, 121, 327-338.

[18] G. M. Sheldrick, Acta Crystallogr., Sect. A 2008, 64, 112-122. 


\section{$478 \quad$ Legends to figures}

479

480 Figure 1. A polynorbornane-based ligand.

481

482 Scheme 1. Preparation of cyclopentadiene 6; DMAP = 4-(dimethylamino) pyridine

483

484

Scheme 2. Synthesis of hexacyclo derivative 12.

485

486 Figure 2. ORTEP representation of one of the enantiomers of alcohol 8.

487

488 Figure 3. ORTEP representation of one of the enantiomers of polycycle

489

12.

490

491 Scheme 3. Synthesis of polycyclo derivative 16.

492

493 Figure 4. ORTEP representation of octacyclo 16.

494

495 


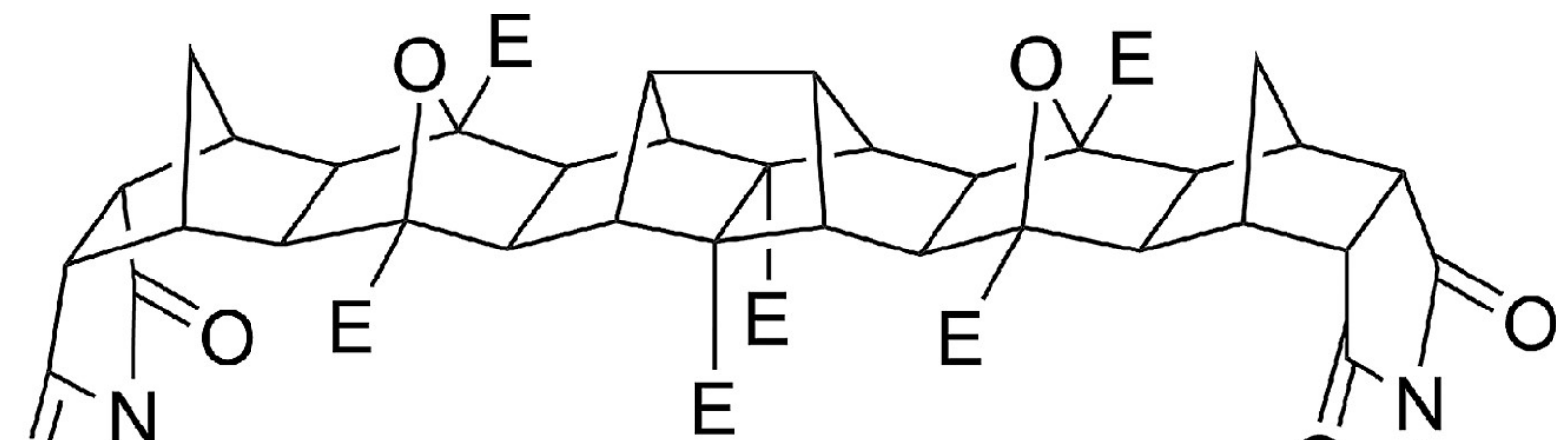

500

$\mathrm{E}=\mathrm{COOMe}$

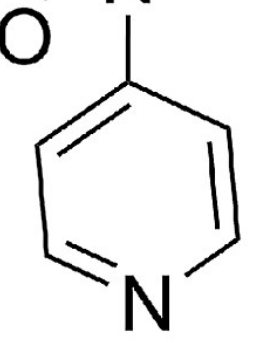


SCHEME 1.

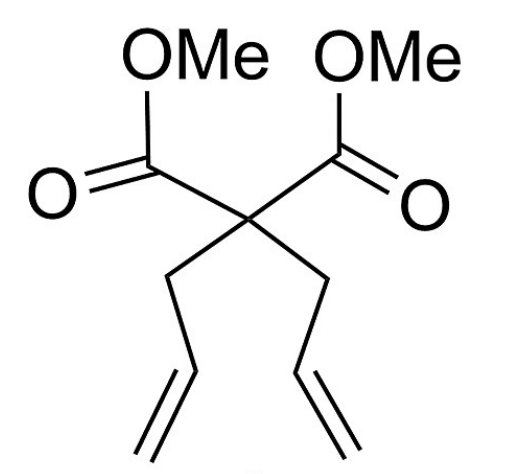

Grubbs first generation catalyst $\mathrm{CH}_{2} \mathrm{Cl}_{2}$, r.t., $20 \mathrm{~h}$ $88 \%$
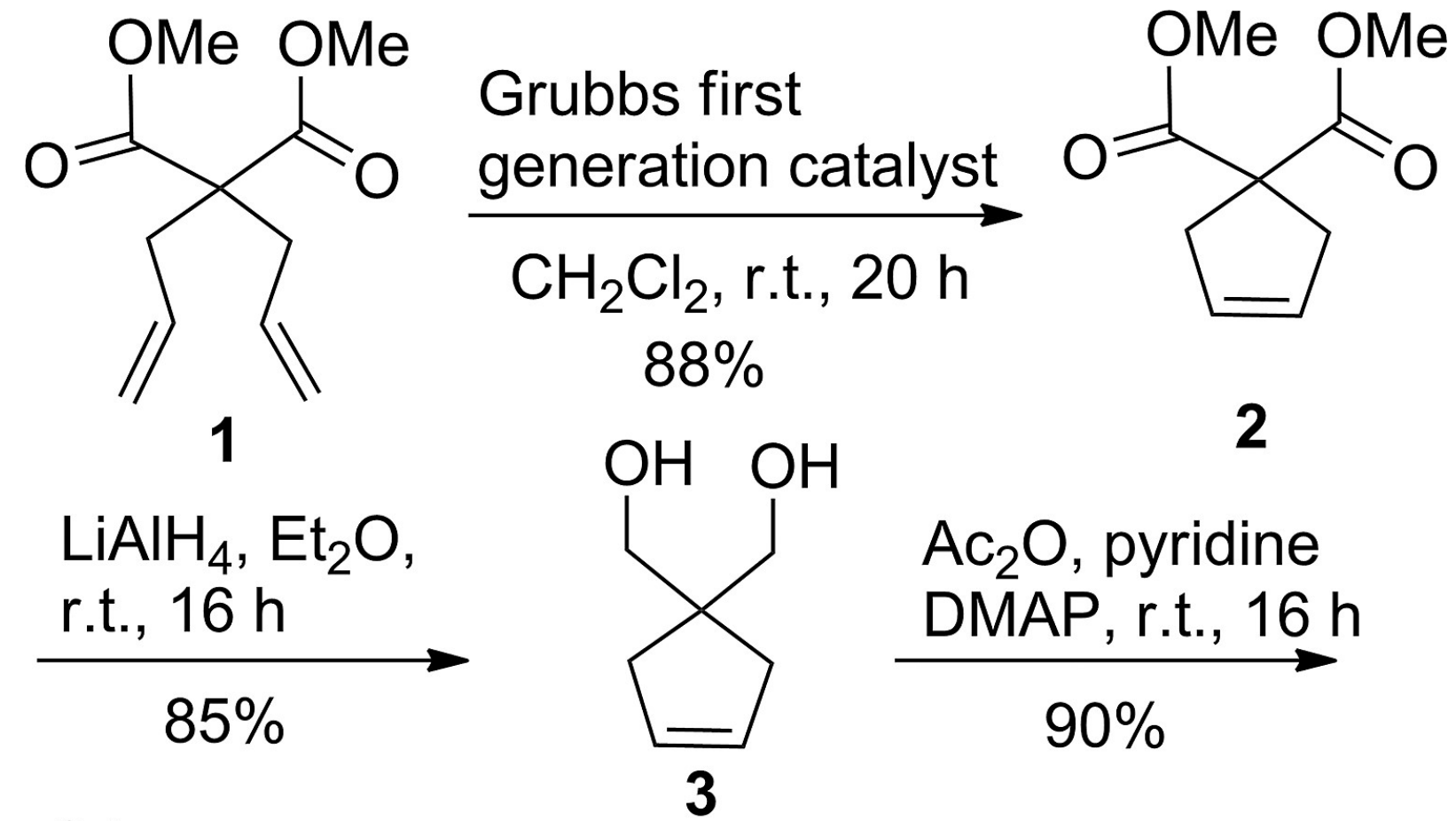

$\mathrm{LiAlH}_{4}, \mathrm{Et}_{2} \mathrm{O}$,

OAc OAc

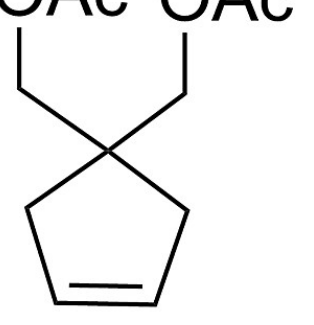

4

quinoline

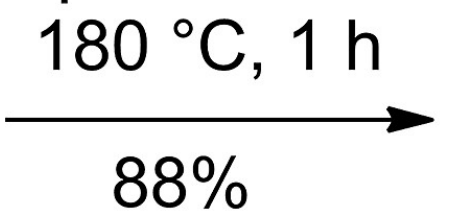

504 505
NBS, AIBN

$\mathrm{CCl}_{4}, 65-90^{\circ} \mathrm{C}$,

$1 \mathrm{~h} 15 \mathrm{~min}$

$$
94 \%
$$

OAc OAc

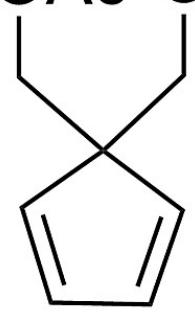

6
$\mathrm{Ac}_{2} \mathrm{O}$, pyridine

DMAP, r.t., $16 \mathrm{~h}$

$90 \%$

OAC OAC

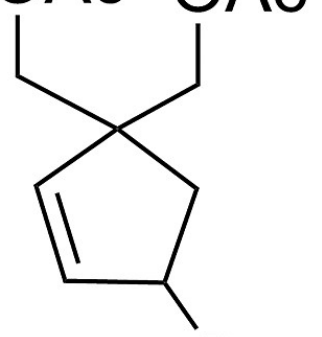

$5 \mathrm{Br}$ 
$\mathrm{K}_{2} \mathrm{CO}_{3}$

$\mathrm{MeOH}$

$30^{\circ} \mathrm{C}, 2 \mathrm{~h}$

$8+9: 53 \%$

8: $32 \%$

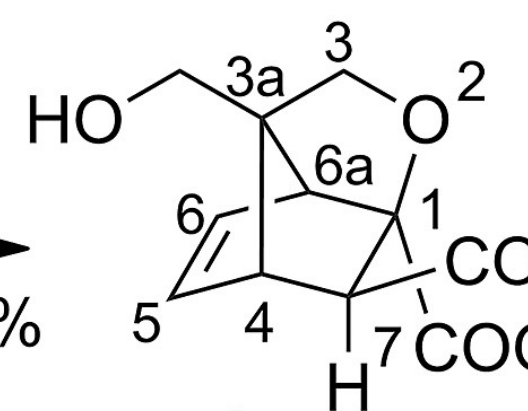

8

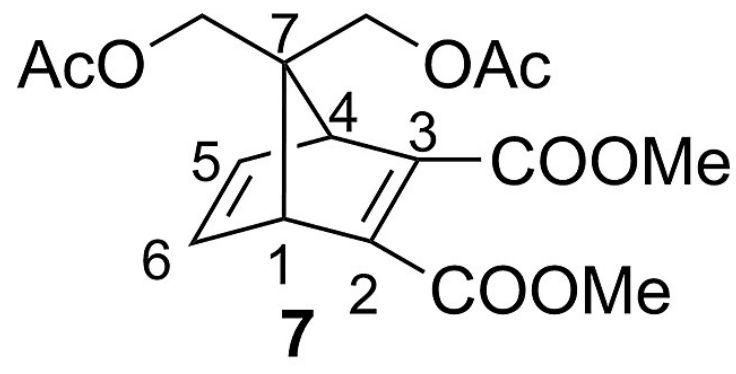

ratio $\mathbf{8} / \mathbf{9}=\mathbf{9 : 1}$

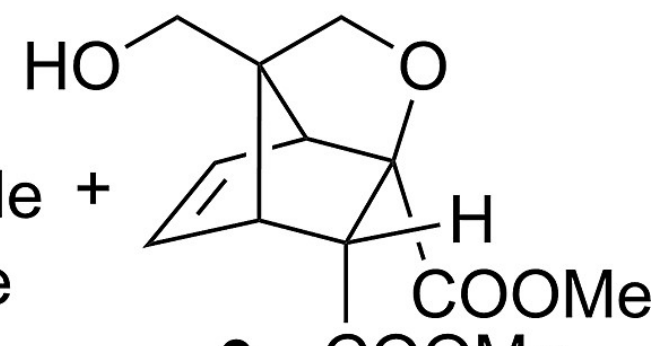

9 COOMe

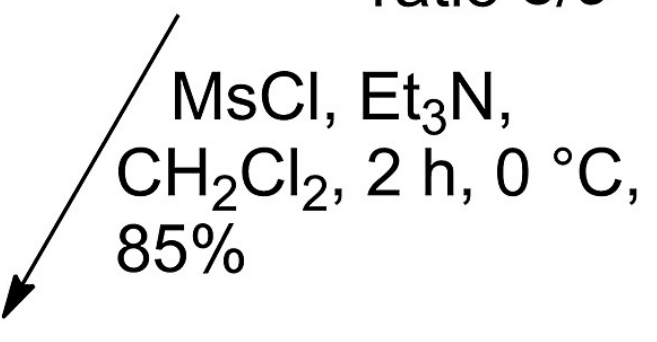

$\mathrm{MsO} \mathrm{O}$ Nal,

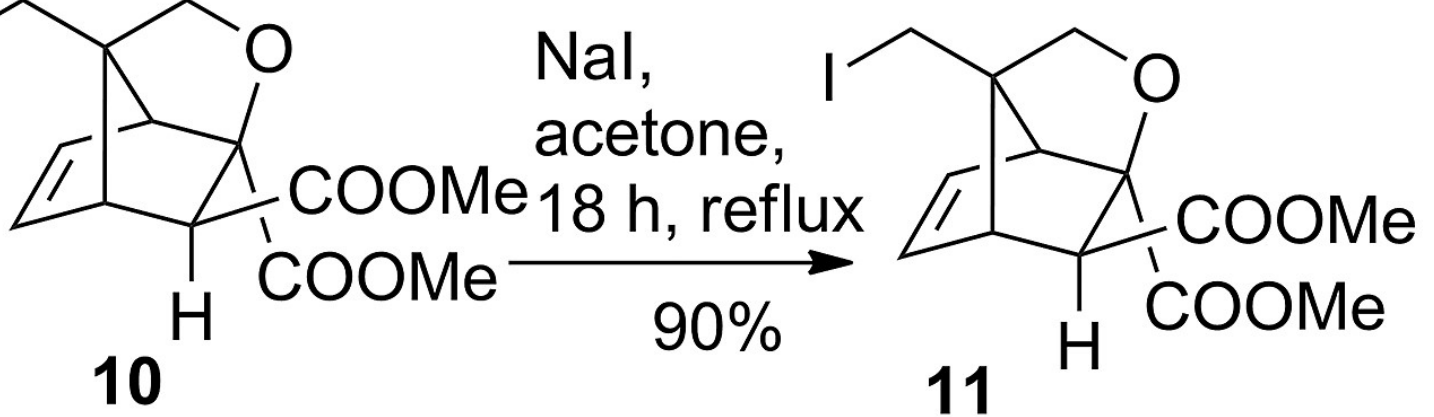

11

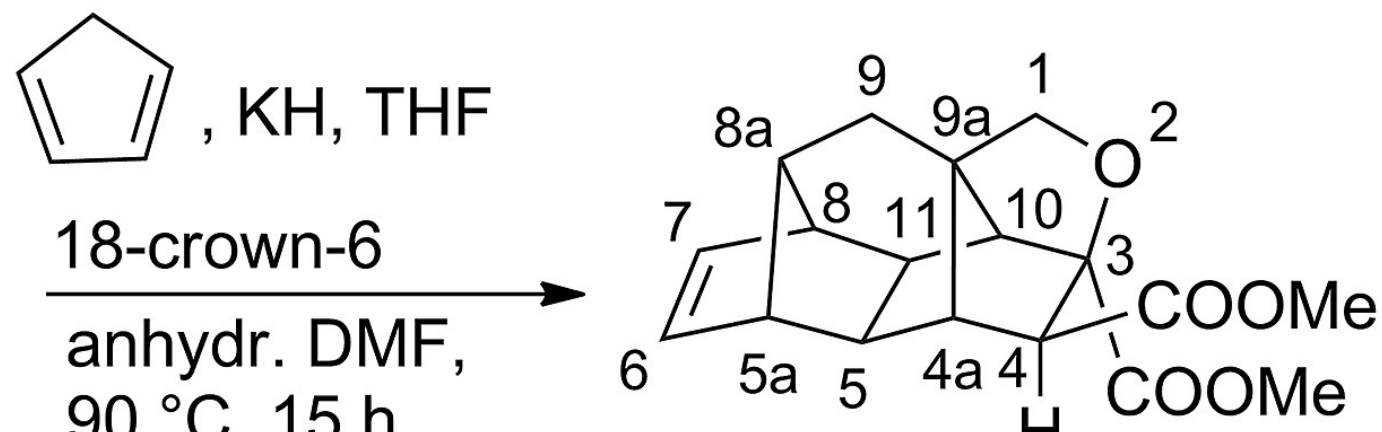
$90{ }^{\circ} \mathrm{C}, 15 \mathrm{~h}$ $60 \%$ 


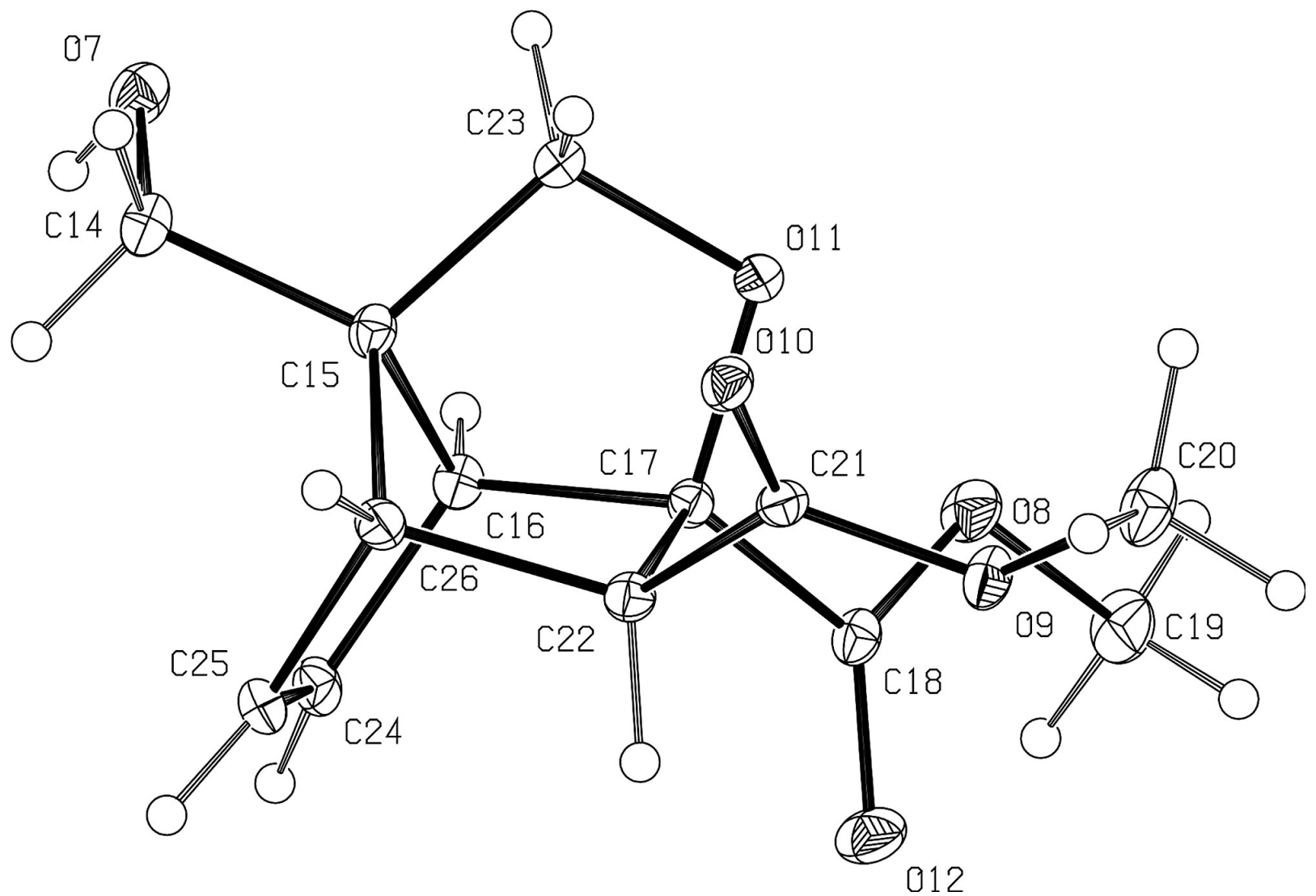




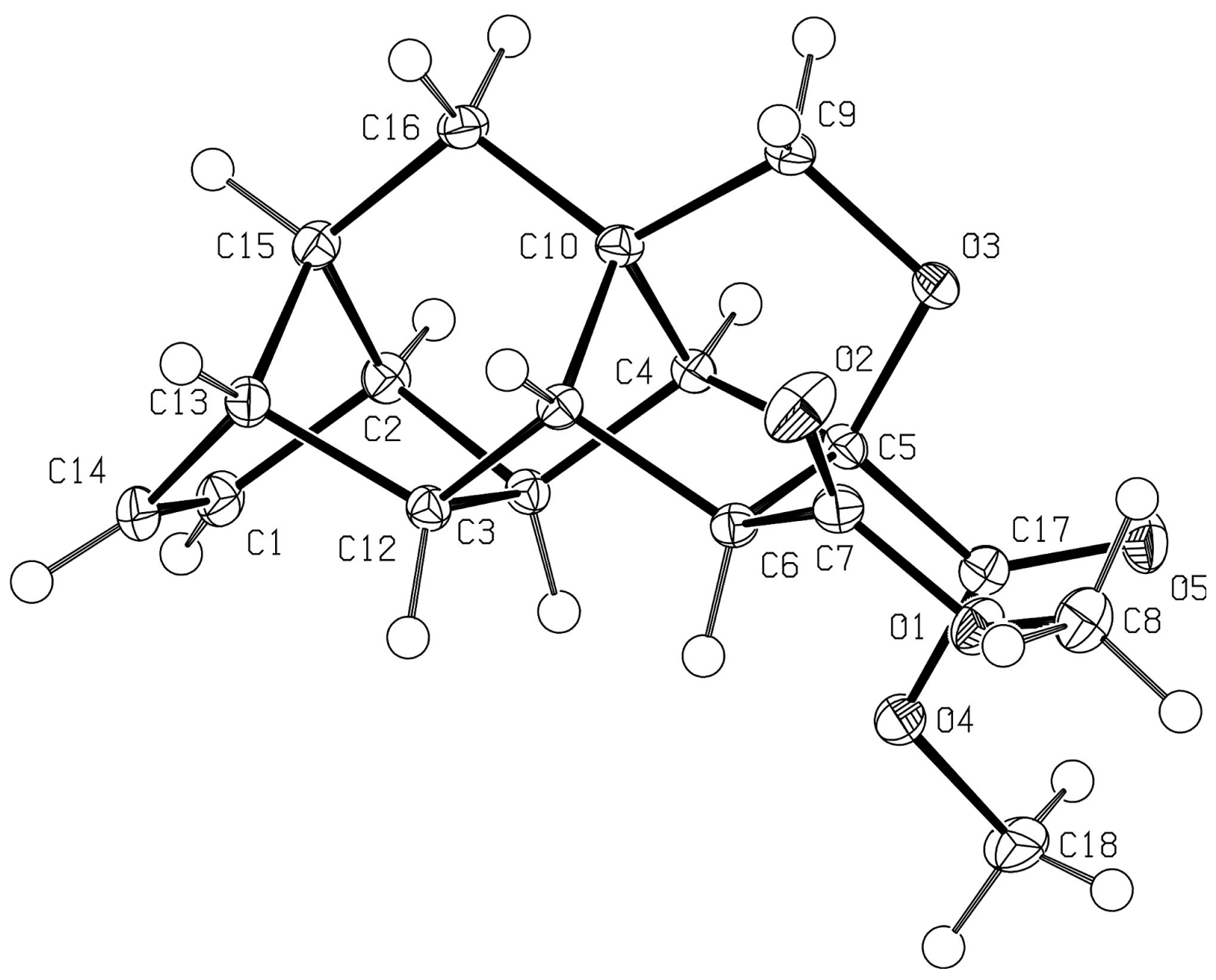




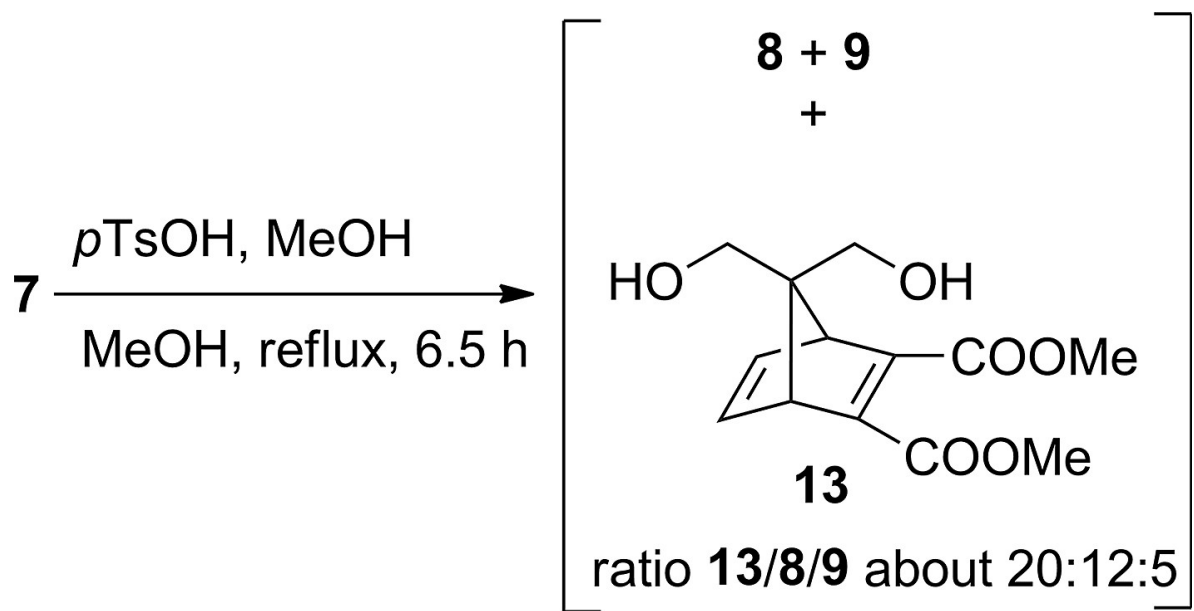

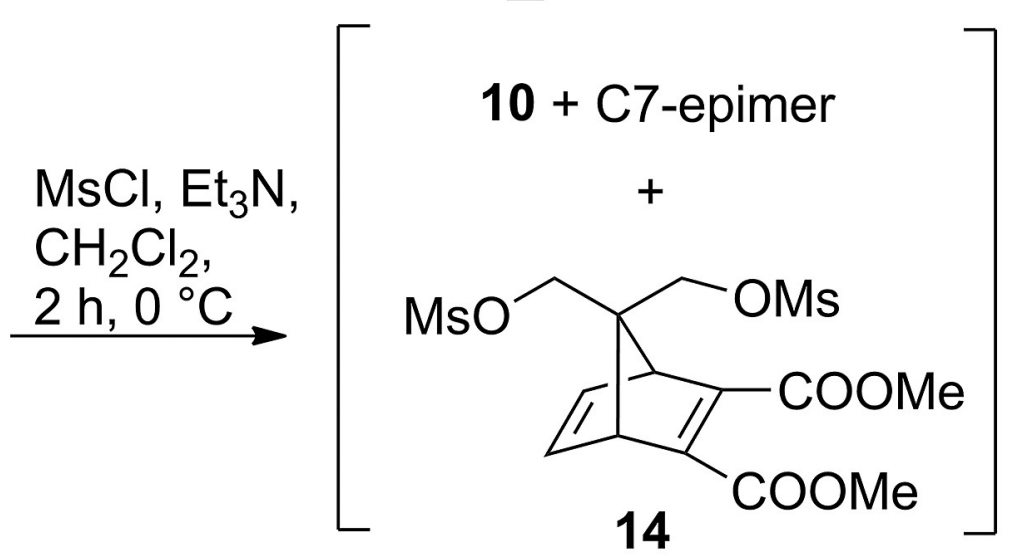

Nal, acetone, $16 \mathrm{~h}$, reflux

$$
\text { 11 + C7-epimer }
$$

Yield from 7:

15: $31 \%$

11 + C7-epimer: $28 \%$<smiles>F[AlH]C1=CC=CC1</smiles>

$15 \underset{\text { anhydr. DMF, }}{\stackrel{\text { 18-crown-6 }}{\longrightarrow}}$ $90{ }^{\circ} \mathrm{C}, 17 \mathrm{~h}$
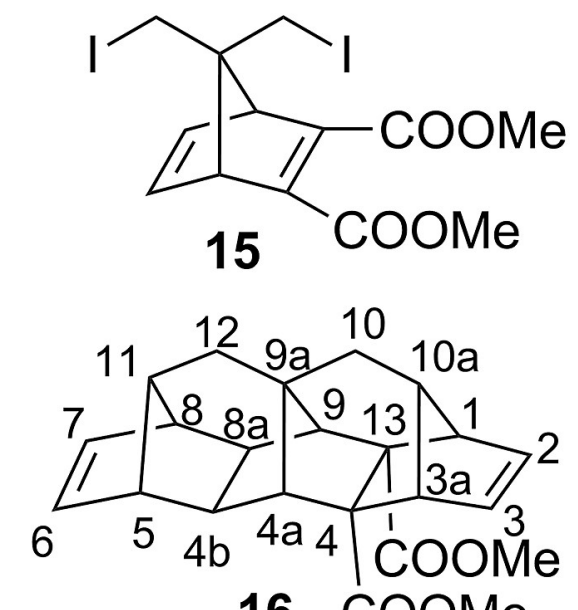
$49 \%$ 


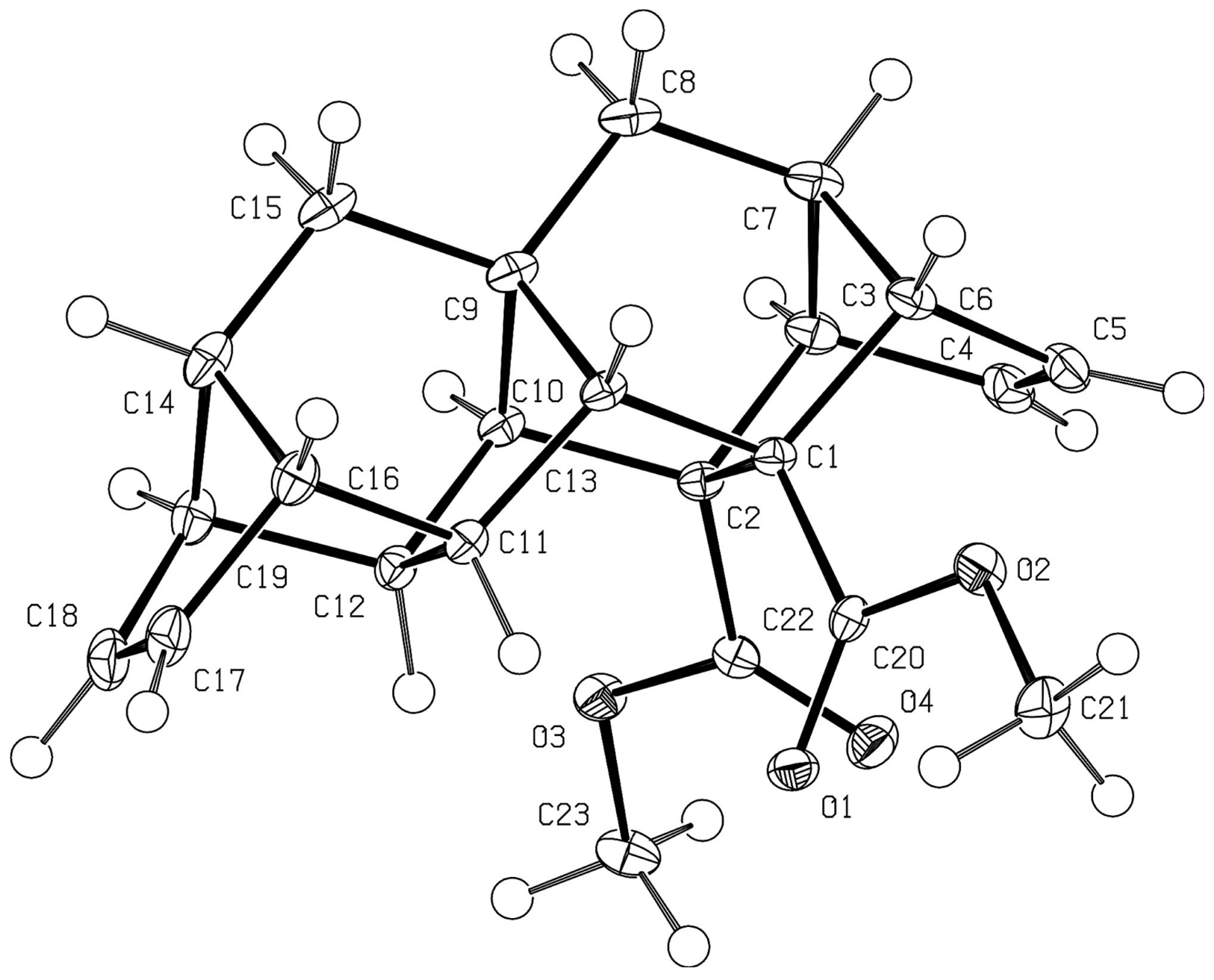

529 
Table 1. Experimental data[a] of the X-ray crystal-structure determination of compounds 8, 12 and 16 .

531

\begin{tabular}{|c|c|c|c|}
\hline & $8^{81}$ & 12 & 16 \\
\hline $\begin{array}{l}\text { Molbcular formula } \\
\text { Molocular mass }\end{array}$ & $\begin{array}{l}\mathrm{C}_{13} \mathrm{H}_{16} \mathrm{O}_{6} \\
268.26\end{array}$ & $\begin{array}{l}\mathrm{C}_{12} \mathrm{H}_{23} \mathrm{O}_{3} \\
316.34\end{array}$ & $\begin{array}{l}\mathrm{C}_{23} \mathrm{H}_{24} \mathrm{O}_{4} \\
364.42\end{array}$ \\
\hline Wavelength & $1.54178 \AA$ & $0.71073 \AA$ & $071073 \AA$ \\
\hline Crystal system & monoclinic & triclinic & monodiric \\
\hline Space group & $P_{2}$ & $P \overline{1}$ & $P 2 / c$ \\
\hline \multicolumn{4}{|l|}{ Unit cell dimensions } \\
\hline$a$ & $5.8773(8) \AA$ & $9.1711(3) \AA$ & $9.6672(4) \AA$ \\
\hline$b$ & $30.253(4) \AA$ & $9.8643(4) \hat{A}$ & $10.5955(5) \AA$ \\
\hline$c$ & $7.0235(9) A$ & $10.2303(4) \AA$ & $17.0696(7) \hat{A}$ \\
\hline$a$ & $90^{\circ}$ & $66.5310(10)^{\circ}$ & $90^{\circ}$ \\
\hline$\beta$ & $100.153(3)^{\circ}$ & $645980(10)^{\circ}$ & $99.698(2)^{\circ}$ \\
\hline 7 & $90^{\circ}$ & $652720(10)^{\circ}$ & $90^{\circ}$ \\
\hline$v$ & $1229.3(3) A^{3}$ & $731.86(5) \hat{A}^{3}$ & $1725.45(13) A^{3}$ \\
\hline$Z$ & 4 & 2 & 4 \\
\hline Dersity & $1.449 \mathrm{Mgm}^{-3}$ & $1.435 \mathrm{Mgm}^{-3}$ & $1.403 \mathrm{Mgm}^{-3}$ \\
\hline Absorption coefficient & $0.977 \mathrm{~mm}^{-1}$ & $0.104 \mathrm{~mm}^{-1}$ & $0.095 \mathrm{~mm}^{-1}$ \\
\hline$F(000)$ & 568 & 336 & 776 \\
\hline Crystal size & $0.578 \times 0.427 \times 0.228 \mathrm{~mm}^{3}$ & $0.554 \times 0.308 \times 0.2 \mathrm{~m} \mathrm{~mm}^{3}$ & $0.285 \times 0.216 \times 0.092 \mathrm{~mm}^{3}$ \\
\hline Theta range for data collection & 2.921 to $72.200^{\circ}$ & 2.287 to $26.446^{\circ}$ & 2.277 to $28.3399^{\circ}$ \\
\hline Index ranges & $-7 \leq h \leq 7 ;-37 \leq k \leq 37 ;-8 \leq 1 \leq 8$ & $-11 \leq h \leq 11 ;-12 \leq k \leq 12,-12 \leq l \leq 12$ & $-12 \leq h \leq 12 ;-14 \leq k \leq 14 ;-22 \leq l \leq 22$ \\
\hline Reflections collected & 13259 & 15320 & 46427 \\
\hline Independent reflactions & $4742\left[R_{n t}=0.0342\right]$ & $3007\left[R_{m 1}=0.0206\right]$ & $4298\left[R_{\mathrm{mt}}=0.0410\right]$ \\
\hline Cocmpleteness to theta & $67.679^{\circ}(98.6 \%)$ & $25.242^{\circ}(99.9 \%)$ & $25.242^{\circ}(99.9 \%)$ \\
\hline Max. and min. transmizion & 0.7536 and 0.6325 & 0.7454 and 0.6847 & 0.7457 and 0.7050 \\
\hline Data/restraints/parameters & $4742 / 1 / 354$ & $3007 / 0210$ & $4298 \% 0258$ \\
\hline Goodness-af-fit on $F^{2}$ & 1.051 & 1.081 & 1.047 \\
\hline Final $R$ indices $[I>2 \sigma(I)]$ & $R_{1}=0.0318, w / 2=0.0670$ & $R_{1}=0.0385, w R 2=0.1033$ & $R_{1}=0.0395, w K 2=0.1017$ \\
\hline$R$ indices (all data) & $R_{1}=0.0319, w R 2=0.0872$ & $R_{1}=0.0299, w R 2=0.1047$ & $R_{1}=0.0486, w K 2=0.1072$ \\
\hline Largest diff. peak and hole & 0.278 and $-0.218 \mathrm{e} \AA^{-3}$ & 0.323 and $-0.292 \mathrm{e}^{-3}$ & 0.364 and $-0.265 \mathrm{e}^{-3}$ \\
\hline
\end{tabular}

